\title{
Democracy and Health: Evidence from Within-Country Heterogeneity in the Congo
}

\author{
Peter van der Windt, Ph.D. \\ Social Science Division, New York University - Abu Dhabi \\ Building A5, Office 147 \\ Saadiyat Island, Abu Dhabi \\ United Arab Emirates \\ Email: petervanderwindt@nyu.edu \\ Tel: +971 26284882 \\ Sotiris Vandoros, Ph.D.* \\ King's College London \\ Bush House \\ 30 Aldwych \\ London WC2B 4BG \\ United Kingdom \\ Email: s.vandoros@kcl.ac.uk \\ Tel: +442078483879
}

10 August 2017

\begin{abstract}
The literature documents a positive association between democracy and health, and studies supporting this claim have largely relied on cross-country panel analyses. In many developing countries, however, local traditional leaders at the micro-level play a key role in individuals' daily lives while the influence of the national government is largely negligible. In response, this study revisits the relationship between democracy and health using micro-level household data from 816 randomly selected villages in Eastern Congo. We find little or no evidence that health outcomes are better in villages that are governed by elected leaders compared to villages where leaders are not elected. Our data suggest that efforts to improve health outcomes in this setting may need to focus on issues such as gender discrimination and education.
\end{abstract}

Keywords: Health; Democracy; Micro-Level; Chiefs; Democratic Republic of Congo

* Paper published in Social Science and Medicine: 2018, 194, 10-16. Corresponding author. We are grateful to the Editor and two anonymous referees for their constructive comments and feedback. We would also like to thank participants at the $12^{\text {th }}$ World Congress on Health Economics, 8-11 July 2017, Boston MA. All outstanding errors are our own. The data for this paper were collected by Van der Windt in collaboration with Macartan Humphreys and Raul Sanchez de la Sierra, the IRC, CARE International, and the universities of Bukavu and Lubumbashi; our deepest thanks to them. We gratefully acknowledge financial support from the International Initiative for Impact Evaluation (grant number: OW2.232). No conflicts of interest arise from this paper. Ethics Approval: Data for this study were collected by one of the two authors (Peter van der Windt) as part of a larger study under the leadership of Macartan Humphreys (PI). IRB approval for data collection has been obtained from Columbia University: IRB-AAAF4550. De-identified data and instruments have been posted online in August 2015:

https://dataverse.harvard.edu/dataset.xhtml?persistentId=doi:10.7910/DVN/BSASJR. The study builds on data from this source. 


\section{Introduction}

Whether democracy affects health outcomes has received a lot of attention. Scholars argue that democracy is related to many positive outcomes from peace (Ray, 1998) to happiness (Inglehart et al, 2008). To date, however, most research exploring the relationship between democracy and health builds on country-level analyses. In this study, we examine this relationship using data that we collected in the Democratic Republic of the Congo, where national politics are largely irrelevant to individuals' daily (health) behaviours, and there is considerable variation in the level of democracy at the micro-level.

Empirically, there is considerable evidence that health outcomes are better under democracy. Besley and Kudamatsu (2006) show that there is better performance in terms of life expectancy at birth and infant mortality in countries that score better on the Polity2 democracy index from the Polity IV database. They also find a positive effect on sanitation, access to clean water, immunisation and health spending. Franco et al (2004) find that more freedom is associated with lower infant and maternal mortality and higher life expectancy. Klomp and De Haan (2009) find a positive relationship between the type of a country's regime and two health measures constructed by the authors (individual health and healthcare sector quality). Ghobarah et al (2004) find that democracies make more funds available for healthcare, while Wigley and Akkoyunlu-Wigley (2011) suggest that there is a positive impact of greater electoral proportionality on life expectancy and infant mortality outcomes. Welander et al (2015) provide empirical evidence that countries with a higher Polity2 democracy score have lower child and infant mortality rates. Presenting case studies on famine and the SARS outbreak, Ruger (2005) argues that the absence of democratic institutions can worsen epidemics. Other studies emphasise the duration of exposure to democracy as a determinant of health or related outcomes (see Pieters et al 2016 on child mortality; Costa-Font and Kossarova 2015 on the effect of the transition of Czechoslovakia to liberal democracy on height; and Besley and Kudamatsu 2006 on life expectancy and infant mortality). However, in a study that focuses on poverty, Ross (2006) suggests that when certain methodological flaws are addressed (country effects, global health trends and sample bias), there is no evidence that democracy benefits poor people. For a table summarising information on health indicators and political dimensions from previous studies, see Klomp and De Haan (2006). 
Theoretically, a number of channels have been put forward via which democracy may promote better population health. Democracy may result in more accountability, and capable individuals might be selected to rule, which can affect health outcomes, for example through willingness to focus on health (e.g. Besley and Kudamatsu, 2006).

The existing literature has examined heterogeneity in health outcomes within countries, which can be attributed to various factors (Subramanian et al 2001; Sun et al 2008; White et al 2011). However, there is a gap in considering heterogeneity in governance within a country as a determinant of health.

The previous empirical studies mentioned above rely largely on cross-country panels and differences in regimes across countries, or changes over time to examine transitions between regimes. This paper advances the literature by studying the link between democracy and health taking advantage of within-country heterogeneity, using micro-level household data that we collected in villages in the Congo. There are three main reasons why we believe this shift in focus is important.

The first reason is substantial. In many developing countries, what happens at the national level has little impact on individuals' daily lives because the reach of the government is low. In contrast, institutions at the micro-level - such as traditional chiefs - govern daily behaviour (Logan 2013; Acemoglu et al, 2014a; Baldwin, 2013, 2016).

Second, exploring the role of democracy at the micro-level is important for policy reasons. International aid organizations seem to have taken a cue from the findings that 1) leaders at the microlevel are key, and 2) democracy is beneficial. In recent years, programs that introduce local institutional innovations have become a favoured model for development, hoping that these will lead to greater accountability of traditional leaders. These programs are undertaken across the world: e.g. Liberia (Fearon et al, 2009), Afghanistan (Beath et al, 2016), Sierra Leone (Casey et al, 2012), Sudan (Avdeenko and Gilligan, 2015). Mansuri and Rao (2013) quote a figure of $\$ 85 \mathrm{bn}$ in World Bank spending in the last decade alone on these types of interventions. A large body of research suggests that institutions are a key driver of economic development (Sokolof and Engerman, 2000; Acemoglu, Johnson and Robinson, 2001; La Porta, Lopez-de Silanes and Shleifer, 2008). There are a number of arguments that support the model of introducing local institutional innovations (i.e. democracy at the local level). There is a conviction that participatory approaches to development will yield better results 
than traditional top-down approaches (e.g. Scott, 1998). Including the voices of local beneficiaries increases their sense of ownership, and is also likely to produce choices that better reflect their needs (Mansuri and Rao, 2013), as well as increase the quality of services provided (Lieberman 2015). The core idea is that the distance between principal and agent is reduced. There are also intrinsic arguments for participatory approaches that emphasize the value of autonomy in determining one's material situation (e.g. Sen, 2001), while local decision-making processes can be inclusive and more democratic. To date, however, we know little about the relationship between democracy and health at this microlevel.

The third reason relates to the mechanism of the impact of democracy on health. Previous studies have shown that democracies make governments more willing to invest in healthcare, which, in turn, can help improve health outcomes (Besley and Kudamatsu 2006; Safaei 2006). However, these villages in the Congo lack resources and infrastructure, meaning that regardless of the willingness to invest in health, this might not be practically possible. Therefore, although we might find a link between democracy and health outcomes in the Congo, as in developed democracies, this relationship might be weaker or non-existent in this setting, due to the absence of resources and infrastructure.

\section{Context, Data Collection and Empirical Strategy}

\subsection{Research Context}

Our data (discussed in detail below), show that individuals in Eastern Congo are poor subsistence farmers, and the typical household has to walk 45 minutes to reach drinking water. Furthermore, (health) infrastructure is largely absent - either due to destruction or lack of investment. Our area of study figured centrally in the violence which has engulfed the country over the last two decades. Eastern Congo was home to the start of the Congolese Wars (1996-1997 and 1998-2003). The latter, with the direct involvement of eight African nations and 25 armed groups, has been the deadliest war in modern African history. It is thus not surprising that health outcomes in Eastern Congo are very poor (WHO 2015). Among our respondents, $18.1 \%$ have been seriously ill (defined as not being able to go to work or school) in the two weeks preceding the survey. Among children under the age of seven, we find that $31.4 \%$ had fever, $26.9 \%$ had a cough and $9.7 \%$ had diarrhoea during the preceding two weeks. These 
numbers are close to the figures provided by the nationally-representative DHS (Demographic and Health Survey), according to which $30 \%$ of children under five had fever the preceding two weeks (DHS, 2014). The corresponding rate for diarrhoea was $17 \%$.

Our data confirm that the central government has little influence on Congolese daily lives. Only $17 \%$ of our respondents know the name of the prime minister, and only $26 \%$ that of the ruling party (compared to, for example, $71 \%$ of Americans that can name the Vice President (Newsweek 2011)). As in many other developing countries, it is not national politics, but local traditional leaders that play a central role in community life (e.g. Logan, 2013). In the Congo, the village chief plays this role. The chief is responsible for community governance, which includes land allocation, mitigating disputes, organising public goods provision, and other issues related to the community. For example, we gave each respondent a hypothetical scenario in which the village received funds and asked who has the most influence on beneficiary selection. A majority of respondents stated that this is the village chief, with only $2 \%$ mentioning the government. Similarly, of all public goods projects undertaken in the village the preceding six months, $33 \%$ were initiated by the village chief, while less than $2 \%$ were initiated by the government. Therefore, individuals' perception on chief influence and the limited role of the central government also reflect reality in Eastern Congo. Given this setting, an investigation into the role of democracy on health outcomes would have to focus on the variation in how traditional leaders gained power, rather than the national government.

Importantly, our data document considerable variation in how village chiefs gained power. The most common form of assuming power is through inheritance (41\%). Some are chosen by the king $(19 \%)$ or by political or traditional leadership (5\%). Others are selected by village elections $(20 \%)$, by village elders $(11 \%)$, or through village referendum (4\%). In this study, a leader is considered elected if they gained power via village elections or referendum. As an informative exercise, 20 villages in the South Kivu province that had reported that the village chief was elected were re-visited in 2017 for an additional short survey. This survey is not representative of our complete sample, nor can it be used to conduct statistical analyses. However, it serves as an informative exercise to provide more information about these elections. The responses show that election rules are not the same in all villages. The reported eligible age to vote was 18 in most villages, but some reported 15, 35 or even 40 years of age. 
Women were reportedly not allowed to vote in 8 out of 20 villages. There were also different responses to the question on the frequency of elections, as in some villages these were repeated every 5, 10, 25 or 30 years, or 'very rarely', while in others the chief was elected for life.

\subsection{Data Collection}

Data were collected in the Congolese provinces of South Kivu, Maniema, Haut Katanga and Tanganyika. Eighty enumerators collected data in two waves: Initially a first wave in 2007, followed by a larger wave in 2012. A total of 942 households (6,056 individuals), in 286 villages, were visited in 2007 that we aimed to visit again in 2012. In 2012, we collected data from 6,015 households $(35,164$ individuals) in 816 villages, and 733 village chiefs. Of these, 219 villages (627 households), were also visited in 2007. The same type of information was collected in 2007 and 2012, with the exception of information on the presence of a health committee and conflict exposure, which were included in the 2012 survey only. In each household, we interviewed one randomly selected adult, who provided information on all other people in the household. Figure 1 shows the location of the 219 panel villages.

The 2012 wave included a much higher number of households, so this (second) wave was the main focus of our analysis and was the subject of our baseline empirical model. However, as an additional check, we also used a panel including the households that were visited in both the 2007 and 2012 waves, subject to having much fewer observations than the baseline model. This is explained further in Sections 2.3 and 3.

Internal Review Board approval for data collection was obtained by [redacted]: [redacted]. Deidentified data, including sampling protocols and survey instruments, can be found online at [redacted].

\section{[Insert Figure 1 here]}

\subsection{Estimation Strategy}

We conducted probit analyses to study the relationship between local democracy and health outcomes. Specifically, we estimated the following equation:

$$
Y_{i}=\alpha+\beta D_{m}+\gamma I_{i}+\delta H_{k}+\zeta V_{m}+\varepsilon_{\iota}
$$


$Y_{i}$ is the dependent variable, representing health outcomes of individual $i$, in household $k$, in village $m$. $D_{m}$ is the main explanatory variable that captures democracy. We have no exogenous variation in whether chiefs are elected (e.g. Acemoglu et al, 2014a) and thus aim to control for a large set of potential confounding factors. $I_{i}$ is a vector that captures individual characteristics; $H_{k}$ captures household characteristics; and $V_{m}$ captures village characteristics. $\varepsilon_{i}$ is a random error term. Congo is home to hundreds of ethnic groups, each with its own customs, clustered geographically in kingdoms. To account for confounding factors at a level higher than the village, including customs that may govern the selection of traditional leaders, we make use of kingdom fixed effects (our study area contains 55 kingdoms). We collected data from five households per village, meaning that data may be clustered by village. We thus clustered the standard errors at the village level. We also perform many robustness tests, which we discuss in the next section.

For our dependent variable, we focus on two sets of outcomes. The first is whether an individual has been seriously ill - defined as not being able to go to school or work during the last two weeks. These data were collected for all individuals in our dataset. Our second set of outcomes focuses on children under the age of seven: whether, over the past two weeks, the child had fever; a cough; or diarrhoea. We chose these particular health outcomes for practical reasons. Respondents have limited knowledge on health outcomes and have hardly any access to diagnosis and treatment. Thus, most diseases, including anything from malaria to cancer, normally go undiagnosed. Furthermore, infant mortality or life expectancy data are not available at the micro-level. Therefore, we needed to ask respondents on simple symptoms that can be easily observed. Being too ill to go to work is something objective, that respondents can answer clearly. The same applies to conditions with obvious symptoms: cough, diarrhoea and fever (high temperature).

The main explanatory variable is democracy, which actually reflects governance in terms of whether the local chief was elected or not, rather than a representation of full democracy. In the Congo, there is considerable variation in the sources of chiefly authority over both space and time. Our measure for democracy - Democracy - is a binary measure indicating whether the current chief came to power through democratic means; that is, via village elections or referendum. Our measure for democracy thus relates to a narrow interpretation of democracy as a form of government in which people choose leaders 
by voting. It is worth noting that this is not directly comparable to modern representative democracies considered in previous studies. Therefore, when referring to 'democracy' hereafter in this paper in the Eastern Congo setting, we mean the type of governance where a chief has been elected.

In $41 \%$ of cases, the current chief obtained power in a different way than the previous chief. Our measure of democracy might thus not correspond well with democratic exposure. In response, we also collected information on how the previous chief assumed power. Combining this information, we create the variable Exposure, which is the number of years there has been democratic rule in the village over the last two decades.

We control for a large set of potential confounding factors. At the individual level, we include age and a dummy variable for gender, as the latter plays an important role on health (McDonough and Walters 2001) and health-related behaviour (Kandrack et al 1991; McDonough and Walters 2001). At the household level, we control for wealth because of the previously reported positive relationship between health and wealth (e.g. Banerjee et al, 2004); and the level of education of the head of the household, as there is a causal effect of education on health (Conti et al 2010). At this level we also control for the distance from a health centre because of any basic type of treatment one can receive if they manage to access such a facility. At the village-level we control for the presence of a health committee as well as NGO activity, because of the positive impact such a presence can have (Mercer et al 2004). We also control for previous experience with conflict (Chobarah et al 2004), the level of ethnic heterogeneity (Zsembik and Fennell 2004), and village isolation.

When including all control variables, the number of observations will be lower than that of the participants. This is in part due to the research area, where respondents often have difficulties accessing information. Older people have difficulties knowing their level of education, while others may have difficulties estimating the distance to the nearest health centre. Therefore, some questions are left unanswered, and as a result some observations drop out of the sample. That is, observations of any individual for whom there is missing information on at least one of the control variables in the empirical model, will automatically be excluded from the model. Therefore, by reducing the number of control variables, we would increase the sample considered in the regression. In the results Section, we address 
this by also running regressions excluding some control variables with missing observations, in order to increase the total number of observations included in the regressions.

A detailed description of each variable is presented in Table A1 in the Online Appendix. Summary statistics can be found in Table 1 . Summary statistics by type of governance (elected chief or not) are presented in Table A2 in the Online Appendix. The mean values for the health outcomes are very close in both types of villages, so an econometric analysis controlling for a number of other factors will help examine whether having an elected chief is related to health outcomes.

The main empirical approach focuses on data collected in 2012. However, as a robustness check, we also performed a panel data analysis, using longitudinal data collected in 2007 and 2012. Using the panel leads to a reduced number of observations because the sample was expanded in 2012, and also means that we aggregated individual observations to the household level. This might decrease precision but allows us to conduct panel analysis as an additional check, taking advantage of the longitudinal element. Table A4 in the Online Appendix presents descriptive information on the panel, separated out by year, where we aggregate (average) health outcomes, age and gender at the household level. The methodological issues raised by Ross (2006) do not apply in our study, as we consider heterogeneity within a country rather than across countries; we include both a cross-section analysis and a panel data approach; and we have a randomised sample from a large number of villages.

\section{[Insert Table 1 here]}

\section{Results}

Table 2 presents the main results, where we report marginal effects from probit regressions, evaluated at the mean of the independent variables, using clustered standard errors at the village level. Having a democratically elected chief does not have a statistically significant effect on the likelihood of being severely ill. When restricting the sample to children under seven, again, there is no impact of having a democratically elected chief on fever, cough or diarrhoea. Columns 5-8 present the results of the model with democratic exposure as the main explanatory variable. We again followed a probit approach, as 
the dependent variable that reflects health outcomes remains binary. We found no effect of the duration of exposure to democracy on severe illness, fever, cough or diarrhoea.

In terms of control variables, columns 1-4 and 5-8 provide largely similar results. We focus on the latter. Gender is important for health. Males are significantly less likely to be ill than females (4.5\%, $p<0.01)$. Compared to girls, boys are also significantly less likely to have fever $(2.4 \%, p<0.05)$, cough $(2.3 \%, p<0.05)$ or diarrhoea $(1.5 \%, p<0.05)$. This may reflect the fact that Congolese society is geared towards men (Van der Windt, 2017). Older children have a much lower likelihood of getting diarrhoea. There is also a strong negative association between years of education of the head of a household and health problems. $18 \%$ of heads of household do not have any primary education, and $64 \%$ do not have any secondary education. Obtaining primary plus secondary schooling (12 years of education in Congo), compared to no schooling, would decrease the likelihood of severe illness by $3.3 \%(p<0.01)$, child fever by $9.3 \%(p<0.01)$ and diarrhoea by $4.7 \%(p<0.01)$. The effect of education on the likelihood of having a cough is not statistically significant. Greater ethnic heterogeneity seems to be associated with a higher likelihood of fever, but does not seem to affect severe illness, cough, or diarrhoea. Village isolation has a negative and statistically significant effect on all four health outcomes. Wealth levels, the presence of a health committee, NGO exposure, and conflict exposure do not appear to have any effect on health outcomes.

When not clustering at the village level, we do find some evidence of a relationship between a democratically elected leader and health (Table A3 in the online appendix). Column 1 shows that there are $1.3 \%$ fewer severely ill individuals in areas with elected leaders, a result that is only somewhat statistically significant $(p<0.1)$. When restricting the sample to children under seven, having an elected chief has no effect on fever, cough, nor diarrhoea (columns 2-4). Columns 5-8 present the results of the model with democratic exposure as the main explanatory variable. We find that an extra year of exposure leads to $0.1 \%$ fewer individuals being severely ill $(p<0.05)$. We find no evidence that exposure to democracy has a statistically significant effect on other health outcomes. Results on control variables are identical to those of the baseline model.

\section{[Insert Table 2 here]}


Table A5 in the Online Appendix presents the results of the panel data analysis, which confirms the results of the baseline model (descriptive information on the panel approach is included in Table A4). While the fixed effects estimator is always consistent, the random effects estimator is more efficient, but not always consistent. We performed a Hausman test to explore which approach we should follow. The $\chi^{2}$ statistic is $12.52(p=0.252)$, suggesting that it is safe to use random effects. Results of the random effects panel model show that there is no evidence in favour of a positive relationship between democracy and health outcomes. In contrast, the head of household's level of education can have a positive effect on health; in three of the eight regressions this relationship is statistically significant $(p<0.05)$.

We performed a large set of robustness tests. First, we explore the importance of other institutional characteristics for health outcomes (Tables A7 to A9 in the Online Appendix; with additional descriptive statistics in Table A6). We find no evidence of a relationship between health outcomes and whether the chief inherited their position; whether the chief obtained power from within or outside the village; or whether the previous chief gained power via elections or referendum. In villages where the previous chief was not elected but the current chief is elected there is a $3.9 \%$ lower incidence of individuals being severely ill $(p<0.01)$. This result, however, does not hold for fever, cough, or diarrhoea. We also find that literacy of the chief (but not education) might affect health outcomes.

Second, as discussed, the difference in observations from Table 1 to Table 2 reflects the fact that some individuals cannot respond to all questions, meaning that observations for such individuals are automatically excluded from these regressions. We drop some covariates in order to increase the number of observations and re-estimate the model. We find no effect of governance on health, while there is again evidence on the importance of gender and education across health outcomes (Table A10 in the Online Appendix).

Next, we present our results by age group. In total, $20.4 \%$ of people in the sample are younger than seven, and the majority (51.4\%) is under eighteen. Column 1 in Table A11 in the Online Appendix presents the relationship between democracy and being severely ill for children under seven, which is 
statistically insignificant. Columns 2-3 present results for children and adults, respectively, with, again, no effect on health. Columns 4-6 present results on democratic exposure. We find that, while education of the head of the household is relevant for children, gender is only relevant for adults. Furthermore, we included household size as an additional control variable, which did not affect the results of the baseline model (Table A12 in the Online Appendix).

\section{Discussion}

The literature suggests a positive relationship between democracy and health outcomes. The studies that support this claim are largely based on country-level analyses. However, in most developing countries, the key actors that govern individuals' daily lives are not to be found at the national level, but at the micro-level, like villages in Congo. Traditional leaders, such as the village chief in Congo, play a key role in community governance, while the state is largely absent. In response, this study examined the relationship between democracy and health in the context of Eastern Congo, using microlevel household data from 816 randomly selected villages. We found little or no evidence supporting that health outcomes are better in villages governed by elected leaders. Most specifications show no link between being severely ill and living in a village with an elected chief, or in a village with greater exposure to an elected leader. Other approaches provide some evidence of a lower likelihood of being severely ill when living in a village with an elected chief, or following a transition from a non-elected to an elected chief. We found no effect on child health outcomes (fever, cough, diarrhoea). It is not obvious why any possible effect is restricted to only the "severely ill" outcome, while children's health remained unaffected. It seems that any association is overall very weak or absent in this particular setting, and certainly not as clear as in previous studies.

There is a plausible explanation why we do not find a strong effect of democracy on health. We explored this association in villages where infrastructure is largely absent, which may be key in explaining our findings. Democracy may make leaders more likely to introduce measures that promote health or other public interventions (Besley and Kudamatsu 2006; Acemoglu and Robinson 2005). However, if lack of resources does not allow for such interventions, democracy might not make that much of a difference for health. In the current conditions and with non-existent resources, there is not 
much an elected village chief can do to invest in health, regardless of their willingness to do so. This also means that our results are not generalisable; and that findings do not dispute the fact that democracy improves health in modern representative democracies via the provision of better health services (Besley and Kudamatsu 2006; Safaei 2006). Democracy has a positive impact on many aspects of society (Acemoglu et al 2014b; Burgess et al 2015; Ray, 1998; Inglehart et al, 2008), and our study only focuses on one particular aspect in a very specific type of society. However, our results are possibly relevant to parts of the developing world, where local chiefs are more important than central government and there are limited resources available for health interventions.

The control variables also generated some interesting findings. Education is associated with better health, which might be a result of more information about the importance of washing hands, water sources, managing health conditions etc. Village isolation is also positively correlated with health, which could possibly be a result of slower spread of diseases due to less interaction with people outside the village. We find strong differences in gender, with males having a lower likelihood of being ill compared to females. These findings provide some information on what else, apart from governance, can help improve health outcomes. This can include efforts to improve access to quality and years of education, as well as tackling discrimination against females, in a society that is geared towards men (Van der Windt 2017). Other possible areas of action, which were not part of our analysis, could include breastfeeding, sanitation and quality of drinking water.

The existing literature has focused mainly on life expectancy and infant and maternal mortality, as well as health funding and quality of services, in order to capture health outcomes (Besley and Kudamatsu 2006; Welander et al 2015; Wigley and Akkoyunlu-Wigley 2011; Franco et al 2004), while a democracy index has been used in most studies as the main explanatory variable. The present study uses different measures for democracy and health outcomes. As discussed, we could not ask respondents on particular diseases such as cancer, malaria, etc. due to limited knowledge or access to diagnosis and treatment, while there was no information on infant mortality rates or life expectancy per village. Therefore, our focus was on symptoms (too ill to go to work, cough, diarrhoea, fever), as opposed to infant mortality or life expectancy that were the focus of analysis in developed countries. This is another reason that prevents direct comparisons to previous studies. However, in terms of 
governance, this unique within-country heterogeneity in whether a local chief was elected or not is a strength of this study, as previous studies largely relied on cross-country panels, and some results could perhaps be affected by unobserved cross-country heterogeneity. Our findings contribute to yet another dimension of within-country heterogeneity, this time in governance, to add to existing variations reported in the health outcomes literature (Subramanian et al 2001; Sun et al 2008; White et al 2011).

There are limitations to this study. We did not have information on breastfeeding, sanitary conditions or quality of water, which can affect health. Furthermore, some individuals were not able to respond to all questions, resulting in missing observations in the full model (some individuals dropping out) - which we addressed by also estimating a model with fewer control variables in order to keep these individuals in. This additional approach led to similar results as the baseline model, and is reassuring regarding any bias due to missing observations. While the chance to hold a chief accountable for their leadership via the next elections could potentially be a factor explaining any differences in outcomes, we had unfortunately not systematically collected information on election frequency during the surveys (except from a small follow-up survey of 20 non-representative villages). The same data limitations hold for possible differences in people's eligibility to vote across villages. Nevertheless, previous studies also grouped together and characterised countries as 'democratic', as long as they had a positive score in the Polity 2 index, even though they experienced different levels of democracy (Besley and Kudamatsu 2006). It is also important to note that democracy in this village setting is not directly comparable to modern democracies involving representative governments that have been considered in previous studies.

Our findings are important for policy. A wide set of development programs that aim to introduce democracy at the micro-level have been implemented in Africa. However, Humphreys et al (2017) studied one such intervention (the Tuungane program in Eastern Congo) and found no evidence that the program affected good governance. The authors conjecture that behavioural change by traditional leaders is unlikely to emerge as a result of (short term) institutional innovations introduced by NGOs. Other randomized control trials exploring similar programs in other parts of the world also found that it is difficult to introduce democratic principles at the micro-level (Fearon et al, 2009; Beath et al, 2016; Casey et al, 2012; Avdeenko and Gilligan, 2015). With this in mind, our findings suggest 
that insofar as improving health outcomes, good governance may not be the single most appropriate short-term target for international aid organisations to focus their attention on. In fact, gender discrimination and education may be a better target for efforts to improve health outcomes. For example, education can prevent the spread of diseases via simple interventions, like washing hands. However, good governance should still be a target in the long-run, when income will increase and more resources will thus become available, allowing for investment in health infrastructure. 


\section{References}

Acemoglu, D., Reed, T., \& Robinson, J. A. (2014a). Chiefs: Economic development and elite control of civil society in Sierra Leone. Journal of Political Economy, 122(2), 319-368.

Acemoglu, D., Naidu, S., Restrepo, P. and Robinson, J.A., (2014b). Democracy does cause growth (No. w20004). National Bureau of Economic Research.

Acemoglu, D. and Robinson, J.A., (2005). Economic origins of dictatorship and democracy. Cambridge University Press.

Acemoglu, D., Johnson, S., \& Robinson, J. (2001). The Colonial Origins of Comparative Development: An Empirical Investigation. American Economic Review, 91(5), 1369-1401.

Avdeenko, A., \& Gilligan, M. J. (2015). International interventions to build social capital: evidence from a field experiment in Sudan. American Political Science Review, 109(3), 427-449.

Baldwin, K. (2013). Why vote with the chief? Political connections and public goods provision in Zambia. American Journal of Political Science, 57(4), 794-809.

Baldwin, K.. (2016). The Paradox of Traditional Chiefs in Democratic Africa. New York City: Cambridge University Press.

Banerjee, A., Deaton, A., \& Duflo, E. (2004). Health, health care, and economic development: Wealth, health, and health services in rural Rajasthan. The American Economic Review, 94(2), 326.

Beath, A., Christia, F., \& Enikolopov, R. (2013). Do elected councils improve governance outcomes? Experimental evidence on local institutions in Afghanistan. World Bank Policy Research Working Paper, 6510.

Besley, T., \& Kudamatsu, M. (2006). Health and democracy. The American Economic Review, 96(2), 313318.

Burgess, R., Jedwab, R., Miguel, E., \& Morjaria, A. (2015). The value of democracy: evidence from road building in Kenya. The American Economic Review, 105(6), 1817-1851.

Casey, K., Glennerster, R., \& Miguel, E. (2012). Reshaping institutions: Evidence on aid impacts using a preanalysis plan. The Quarterly Journal of Economics, 127(4), 1755-1812.

Conti, G., Heckman, J., \& Urzua, S. (2010). The education-health gradient. The American economic review, 100(2), 234.

Costa-Font, J., \& Kossarova, L. (2014). Anthropometric Dividends of Czechoslovakia's Break Up. LSE 'Europe in Question' Discussion Paper Series, 95/2015.

DHS. 2014. Demographic and Health Surveys. Democratic Republic of the Congo.

Fearon, J. D., Humphreys, M., \& Weinstein, J. M. (2009). Can development aid contribute to social cohesion after civil war? Evidence from a field experiment in post-conflict Liberia. The American Economic Review, 99(2), 287-291.

Franco, Á., Álvarez-Dardet, C., \& Ruiz, M. T. (2004). Effect of democracy on health: ecological study. BMJ, 329(7480), 1421-1423.

Ghobarah, H. A., Huth, P., \& Russett, B. (2004). Comparative public health: The political economy of human misery and Well-Being. International Studies Quarterly, 48(1), 73-94.

Ghobarah, H. A., Huth, P., \& Russett, B. (2004). The post-war public health effects of civil conflict. Social Science \& Medicine, 59(4), 869-884.

Humphreys, Macartan, Raul Sanchez de la Sierra, and Peter Van der Windt. 2017. "Social Engineering in the Tropics: A Grassroots Democratization Experiment in the Congo.” Working paper.

Inglehart, R., Foa, R., Peterson, C., \& Welzel, C. (2008). Development, freedom, and rising happiness: A global perspective (1981-2007). Perspectives on Psychological Science, 3(4), 264-285.

Kandrack, M. A., Grant, K. R., \& Segall, A. (1991). Gender differences in health related behaviour: some unanswered questions. Social Science \& Medicine, 32(5), 579-590.

Klomp, J., \& De Haan, J. (2009). Is the political system really related to health?. Social Science \& Medicine, 69(1), 36-46.

Lieberman S.E. (2015). The comparative Politics of Service Delivery in Developing Countries, In: Lancaster C. and van de Walle N. (eds.) The Oxford Handbook of Politics of Development, Oxford University Press

Logan, C. (2013). The roots of resilience: Exploring popular support for African traditional authorities. African Affairs, 112(448), 353-376.

Mansuri, G, and V Rao. (2013). Localizing Development: Does Participation Work? World Bank Policy Report. Washington DC.

McDonough, P., \& Walters, V. (2001). Gender and health: reassessing patterns and explanations. Social Science \& Medicine, 52(4), 547-559. 
Mercer, A., Khan, M. H., Daulatuzzaman, M., \& Reid, J. (2004). Effectiveness of an NGO primary health care programme in rural Bangladesh: evidence from the management information system. Health Policy and Planning, 19(4), 187-198.

Newsweek. 2011. How Ignorant are Americans? Date: 20 March 2011. Available at: http://www.newsweek.com/how-ignorant-are-americans-66053 Accessed 5 August 2017.

Pieters, H., Curzi, D., Olper, A., \& Swinnen, J. (2016). Effect of democratic reforms on child mortality: a synthetic control analysis. The Lancet Global Health, 4(9), e627-e632.

Ray, J. L. (1998). Does democracy cause peace?. Annual Review of Political Science, 1(1), $27-46$.

Ross, M. (2006). Is democracy good for the poor?. American Journal of Political Science, 50(4), 860-874.

Ruger, J. P. (2005). Democracy and health. QJM, 98(4), 299-304.

Safaei, J. (2006). Is democracy good for health?. International Journal of Health Services, 36(4), 767-786.

Scott, J. C. (1998). Seeing Like a State: How Certain Schemes to Improve the Human Condition have Failed. New Haven: Yale University Press.

Sen, A. (2001). Development as Freedom. New York City: Oxford University Press.

Sokoloff, K. L., \& Engerman, S. L. (2000). History lessons: Institutions, factors endowments, and paths of development in the new world. The Journal of Economic Perspectives, 14(3), 217-232.

Subramanian, S. V., Kawachi, I., \& Kennedy, B. P. (2001). Does the state you live in make a difference? Multilevel analysis of self-rated health in the US. Social Science \& Medicine, 53(1), 9-19.

Sun, S., Chen, J., Johannesson, M., Kind, P., Xu, L., Zhang, Y., \& Burström, K. (2011). Regional differences in health status in China: Population health-related quality of life results from the National Health Services Survey 2008. Health \& Place, 17(2), 671-680.

Van der Windt, Peter. 2017. "Can Development Lead to Women Empowerment? Evidence from a Field Experiment in the Congo." Working paper.

Welander, A., Lyttkens, C. H., \& Nilsson, T. (2015). Globalization, democracy, and child health in developing countries. Social Science \& Medicine, 136, 52-63.

White, H. L., Matheson, F. I., Moineddin, R., Dunn, J. R., \& Glazier, R. H. (2011). Neighbourhood deprivation and regional inequalities in self-reported health among Canadians: Are we equally at risk?. Health \& Place, 17(1), 361-369.

Wigley, S., \& Akkoyunlu-Wigley, A. (2011). Do electoral institutions have an impact on population health?. Public Choice, 148(3-4), 595-610.

World Health Organisation 2015. Democratic Republic of Congo: WHO Statistical Profile. Available at: http://www.who.int/gho/countries/cod.pdf?ua=1 Accessed: 20 August 2017.

Zsembik, B. A., \& Fennell, D. (2005). Ethnic variation in health and the determinants of health among Latinos. Social Science \& Medicine, 61(1), 53-63. 
Figure 1. Research Area

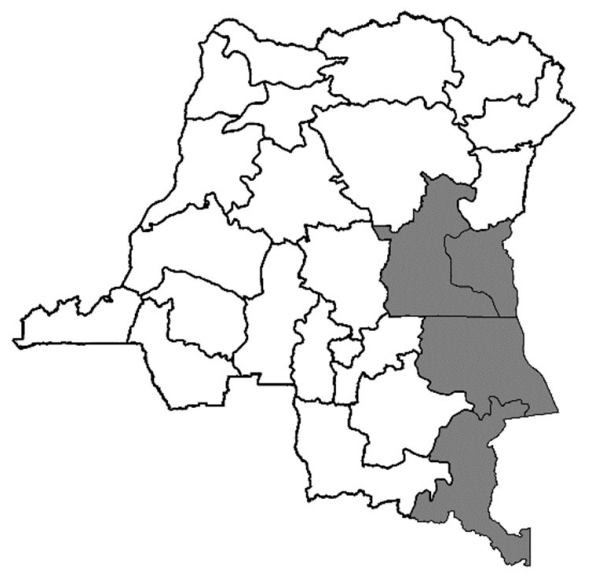

(a) DRC

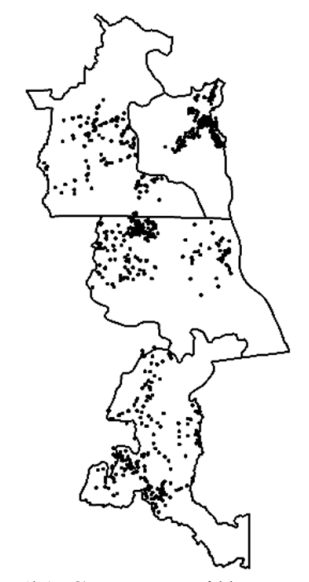

(b) Survey Villages

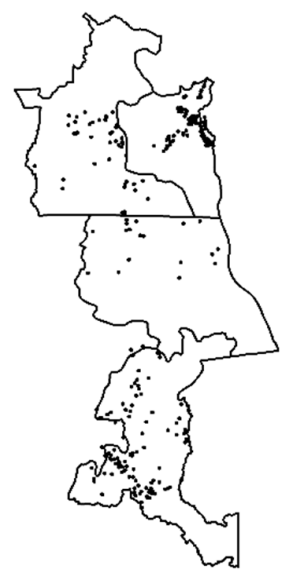

(c) Panel Villages

Notes: Authors' drawing. Panel (a): The provinces of (top to bottom) Maniema, South Kivu, Tanganyika and Haut Katanga are highlighted. Panel (b): 2012 survey villages. Panel (c): Villages visited in 2012 and 2007. 
Table 1. Descriptive Statistics

\begin{tabular}{|c|c|c|c|c|c|c|}
\hline \# & Variable (unit) & $\mathbf{N}$ & Mean & SD & Min & Max \\
\hline 1 & Severely ill & 33,639 & 0.181 & 0.385 & 0 & $\overline{1}$ \\
\hline 2 & Fever (children U7 only) & 10,287 & 0.314 & 0.464 & 0 & 1 \\
\hline 3 & Cough (children U7 only) & 10,291 & 0.269 & 0.444 & 0 & 1 \\
\hline 4 & Diarrhoea (children U7 only) & 10,189 & 0.097 & 0.295 & 0 & 1 \\
\hline 5 & Democracy & 30,892 & 0.260 & 0.439 & 0 & 1 \\
\hline 6 & Exposure & 31,091 & 4.070 & 7.302 & 0 & 20 \\
\hline 7 & Age (10 years) & 33,641 & 2.178 & 1.773 & 0.1 & 10.6 \\
\hline 8 & Male & 34,741 & 0.505 & 0.500 & 0 & 1 \\
\hline 9 & Wealth & 34,850 & 7.727 & 3.394 & 1 & 27 \\
\hline 10 & Education household head (years) & 34,384 & 0.077 & 0.266 & 0 & 1 \\
\hline 11 & Distance nearest health center (hours) & 27,443 & 4.415 & 3.444 & 0 & 15 \\
\hline 12 & Health committee & 30,919 & 2.117 & 5.366 & 0 & 96 \\
\hline 13 & NGO exposure & 31,801 & 0.557 & 0.497 & 0 & 1 \\
\hline 14 & Conflict exposure & 29,789 & 0.806 & 0.395 & 0 & 1 \\
\hline 15 & Ethnic heterogeneity & 30,958 & 1.373 & 7.670 & 0 & 120 \\
\hline 16 & Village isolation (hours) & 31,777 & 0.321 & 0.276 & 0 & 0.82 \\
\hline 17 & Household size & 34,850 & 7.727 & 3.40 & 1 & 27 \\
\hline
\end{tabular}

Notes: Based on survey data. Details in the Online Appendix. 
Table 2. Democracy and Health Outcomes

\begin{tabular}{|c|c|c|c|c|c|c|c|c|}
\hline & $\begin{array}{c}(1) \\
\text { Severely ill }\end{array}$ & $\begin{array}{c}(2) \\
\text { Fever }\end{array}$ & $\begin{array}{c}(3) \\
\text { Cough }\end{array}$ & $\begin{array}{c}(4) \\
\text { Diarrhoea }\end{array}$ & $\begin{array}{c}(5) \\
\text { Severely ill } \\
\end{array}$ & $\begin{array}{c}(6) \\
\text { Fever }\end{array}$ & $\begin{array}{c}(7) \\
\text { Cough }\end{array}$ & $\begin{array}{c}(8) \\
\text { Diarrhoea }\end{array}$ \\
\hline Democracy & $\begin{array}{l}-0.013 \\
(0.011)\end{array}$ & $\begin{array}{c}-0.012 \\
(0.020)\end{array}$ & $\begin{array}{c}-0.001 \\
(0.022)\end{array}$ & $\begin{array}{c}0.002 \\
(0.011)\end{array}$ & & & & \\
\hline Exposure & & & & & $\begin{array}{l}-0.001 \\
(0.001)\end{array}$ & $\begin{array}{c}0.000 \\
(0.001) \\
\end{array}$ & $\begin{array}{c}0.001 \\
(0.001) \\
\end{array}$ & $\begin{array}{c}0.000 \\
(0.001) \\
\end{array}$ \\
\hline Male & $\begin{array}{c}-0.046^{* * *} \\
(0.005)\end{array}$ & $\begin{array}{l}-0.023^{*} \\
(0.012)\end{array}$ & $\begin{array}{l}-0.021^{*} \\
(0.012)\end{array}$ & $\begin{array}{c}-0.015^{* *} \\
(0.008)\end{array}$ & $\begin{array}{c}-0.045^{* * * *} \\
(0.005)\end{array}$ & $\begin{array}{c}-0.024^{* * *} \\
(0.012)\end{array}$ & $\begin{array}{l}-0.023^{*} \\
(0.012)\end{array}$ & $\begin{array}{l}-0.015^{* *} \\
(0.008)\end{array}$ \\
\hline Age & $\begin{array}{c}0.007 \\
(0.006)\end{array}$ & $\begin{array}{c}0.070 \\
(0.106)\end{array}$ & $\begin{array}{l}-0.090 \\
(0.099)\end{array}$ & $\begin{array}{c}-0.281^{\text {**** }} \\
(0.065)\end{array}$ & $\begin{array}{c}0.006 \\
(0.006)\end{array}$ & $\begin{array}{c}0.086 \\
(0.106)\end{array}$ & $\begin{array}{l}-0.043 \\
(0.100)\end{array}$ & $\begin{array}{c}-0.285^{\text {**** }} \\
(0.065)\end{array}$ \\
\hline $\mathrm{Age}^{2}$ & $\begin{array}{c}0.003^{* * * *} \\
(0.001)\end{array}$ & $\begin{array}{c}-0.275^{* * *} \\
(0.101)\end{array}$ & $\begin{array}{l}-0.123 \\
(0.094)\end{array}$ & $\begin{array}{l}0.117^{*} \\
(0.065)\end{array}$ & $\begin{array}{c}0.004^{* * * *} \\
(0.001)\end{array}$ & $\begin{array}{c}-0.297^{* * *} \\
(0.101)\end{array}$ & $\begin{array}{l}-0.174^{*} \\
(0.095)\end{array}$ & $\begin{array}{c}0.118^{*} \\
(0.065)\end{array}$ \\
\hline Education & $\begin{array}{c}-0.003^{* * *} \\
(0.001)\end{array}$ & $\begin{array}{c}-0.007^{* * * *} \\
(0.002)\end{array}$ & $\begin{array}{l}-0.004 \\
(0.002)\end{array}$ & $\begin{array}{c}-0.004^{* * *} \\
(0.001)\end{array}$ & $\begin{array}{c}-0.003^{* * *} \\
(0.001)\end{array}$ & $\begin{array}{c}-0.007^{* * *} \\
(0.002)\end{array}$ & $\begin{array}{l}-0.003 \\
(0.002)\end{array}$ & $\begin{array}{c}-0.004^{* * *} \\
(0.001)\end{array}$ \\
\hline Wealth & $\begin{array}{l}-0.021 \\
(0.017)\end{array}$ & $\begin{array}{c}-0.014 \\
(0.031)\end{array}$ & $\begin{array}{l}-0.017 \\
(0.029)\end{array}$ & $\begin{array}{c}0.007 \\
(0.019)\end{array}$ & $\begin{array}{l}-0.021 \\
(0.017)\end{array}$ & $\begin{array}{l}-0.017 \\
(0.031)\end{array}$ & $\begin{array}{l}-0.019 \\
(0.029)\end{array}$ & $\begin{array}{c}0.005 \\
(0.019)\end{array}$ \\
\hline Distance & $\begin{array}{l}-0.001 \\
(0.001)\end{array}$ & $\begin{array}{l}0.003^{* *} \\
(0.002)\end{array}$ & $\begin{array}{l}0.003^{* *} \\
(0.002)\end{array}$ & $\begin{array}{c}0.000 \\
(0.001)\end{array}$ & $\begin{array}{l}-0.001 \\
(0.001)\end{array}$ & $\begin{array}{l}0.003^{* *} \\
(0.002)\end{array}$ & $\begin{array}{l}0.003^{* *} \\
(0.002)\end{array}$ & $\begin{array}{c}0.000 \\
(0.001)\end{array}$ \\
\hline Committee & $\begin{array}{l}-0.005 \\
(0.012)\end{array}$ & $\begin{array}{c}-0.01 \\
(0.019)\end{array}$ & $\begin{array}{c}0.012 \\
(0.021)\end{array}$ & $\begin{array}{l}0.004 \\
(0.01)\end{array}$ & $\begin{array}{l}-0.004 \\
(0.012)\end{array}$ & $\begin{array}{l}-0.011 \\
(0.019)\end{array}$ & $\begin{array}{c}0.01 \\
(0.020)\end{array}$ & $\begin{array}{c}0.003 \\
(0.010)\end{array}$ \\
\hline NGO & $\begin{array}{c}0.000 \\
(0.015)\end{array}$ & $\begin{array}{c}0.024 \\
(0.025)\end{array}$ & $\begin{array}{c}0.013 \\
(0.027)\end{array}$ & $\begin{array}{c}-0.002 \\
(0.013)\end{array}$ & $\begin{array}{l}-0.002 \\
(0.015)\end{array}$ & $\begin{array}{c}0.02 \\
(0.025)\end{array}$ & $\begin{array}{c}0.011 \\
(0.026)\end{array}$ & $\begin{array}{l}-0.002 \\
(0.013)\end{array}$ \\
\hline Conflict & $\begin{array}{c}0.000 \\
(0.001)\end{array}$ & $\begin{array}{c}0.001^{*} \\
(0.001)\end{array}$ & $\begin{array}{c}0.001^{*} \\
(0.001)\end{array}$ & $\begin{array}{c}0.000 \\
(0.001)\end{array}$ & $\begin{array}{c}0.000 \\
(0.001)\end{array}$ & $\begin{array}{c}0.001^{*} \\
(0.001)\end{array}$ & $\begin{array}{l}0.001^{*} \\
(0.001)\end{array}$ & $\begin{array}{c}0.000 \\
(0.001)\end{array}$ \\
\hline Ethnic & $\begin{array}{l}-0.002 \\
(0.025)\end{array}$ & $\begin{array}{l}0.095^{* *} \\
(0.043)\end{array}$ & $\begin{array}{c}0.030 \\
(0.046)\end{array}$ & $\begin{array}{c}0.012 \\
(0.023)\end{array}$ & $\begin{array}{l}-0.004 \\
(0.025)\end{array}$ & $\begin{array}{l}0.098^{* *} \\
(0.043)\end{array}$ & $\begin{array}{c}0.032 \\
(0.046)\end{array}$ & $\begin{array}{c}0.015 \\
(0.022)\end{array}$ \\
\hline Isolation & $\begin{array}{c}-0.001^{* * *} \\
(0.001)\end{array}$ & $\begin{array}{c}-0.002^{* * * *} \\
(0.001)\end{array}$ & $\begin{array}{c}-0.002^{* *} \\
(0.001)\end{array}$ & $\begin{array}{c}-0.001^{* * *} \\
(0.000)\end{array}$ & $\begin{array}{c}-0.001^{* *} \\
(0.001)\end{array}$ & $\begin{array}{c}-0.002^{* * * *} \\
(0.001)\end{array}$ & $\begin{array}{c}-0.002^{* *} \\
(0.001)\end{array}$ & $\begin{array}{c}-0.001^{* *} \\
(0.000)\end{array}$ \\
\hline HH size & $\begin{array}{c}-0.013 \\
(0.011)\end{array}$ & $\begin{array}{l}-0.012 \\
(0.020)\end{array}$ & $\begin{array}{l}-0.001 \\
(0.022)\end{array}$ & $\begin{array}{c}0.002 \\
(0.011)\end{array}$ & $\begin{array}{l}-0.001 \\
(0.001)\end{array}$ & $\begin{array}{c}0.000 \\
(0.001)\end{array}$ & $\begin{array}{c}0.001 \\
(0.001)\end{array}$ & $\begin{array}{c}0.000 \\
(0.001)\end{array}$ \\
\hline FEs & $\mathrm{Y}$ & $\mathrm{Y}$ & $\mathrm{Y}$ & $\bar{Y}$ & $\bar{Y}$ & $\mathrm{Y}$ & $\mathrm{Y}$ & $\mathrm{Y}$ \\
\hline Sample & All & U7 & U7 & U7 & All & U7 & U7 & U7 \\
\hline Kingdoms & 55 & 55 & 55 & 55 & 55 & 55 & 55 & 55 \\
\hline $\mathrm{N}$ & 17,602 & 5,698 & 5,700 & 5,623 & 17,759 & 5,749 & 5,751 & 5,676 \\
\hline
\end{tabular}

Notes: Marginal effects from probit regressions with kingdom fixed effects. Standard errors (clustered at the village level) in parentheses. ${ }^{*} \mathrm{p}<0.10, * * \mathrm{p}<0.05, * * * \mathrm{p}<0.01$. 


\section{Online Appendix}

\section{Online Appendix: Village, Household and Respondent Selection}

Villages were randomly selected, as were households within villages. Within households, the respondent was randomly selected. In this section, we briefly discuss the randomization strategies used in each step. The full set of details and the complete set of protocols can be found online: [redacted].

\section{Village selection}

To create a village-level sampling frame, we utilized a dataset that we created together with the International Rescue Committee and CARE International in 2006, and updated in 2010. In brief, all chiefdoms in the provinces Maniema, South Kivu, Haut Katanga and Tanganyika were visited to create a complete list of all villages in these provinces. The 2006 and 2010 lists included over 5,500 and 8,000 villages, respectively. From this list, a random sample of villages was drawn, ensuring balance across chiefdom.

In the case the village was not there or empty (villagers may have fled from conflict), or the chief declined to do research in the village (both occurrences are rare), the research team had provided the survey teams with randomly selected replacement villages.

\section{Household selection}

Within villages, five households were randomly selected. The selection procedure went as follows. Our enumerators would make a list together with the village chief and other knowledgeable individuals of all households in the village. Then they would make use of a random numbers table to select five households.

In the case the household was not there or refused to be interviewed, the replacement went as follows. With the surveyor's back to the door, the surveyor would then choose the household on their right.

\section{Respondent selection}

Within the household we randomly selected one individual to be the respondent. We ensured that half of the respondents were men, half were women. The process went as follows. The surveyor would create a list of all the individuals in the household that are adult and of the gender indicated in the enumerator dictionary. The surveyor dictionary (created by the research team) would then indicate, for different sizes of households, a random number of the person to be selected on the created list.

If an individual refused to respond, the next person on the list was to be selected. 
Online Appendix: Variable Definitions

Table A1. Variable Definitions

\begin{tabular}{|c|c|c|c|}
\hline Variable & Description & Level & $\begin{array}{l}\text { Question } \\
\text { number }\end{array}$ \\
\hline Severely ill & $\begin{array}{l}\text { Binary. Severely ill, defined as not been able to go to } \\
\text { school or work, during previous two weeks. }\end{array}$ & Individual & QF21 \\
\hline Fever & Binary. Fever during the last two weeks. & Children U7 & QF20 \\
\hline Cough & Binary. Cough during the last two weeks. & Children U7 & QF20 \\
\hline Diarrhoea & Binary. Diarrhoea during the last two weeks. & Children U7 & QF20 \\
\hline Democracy & $\begin{array}{l}\text { Binary. We record whether chiefs assumed power via: } \\
\text { inheritance, chosen by the king, chosen by political or } \\
\text { traditional leadership, village elections, village elders, or } \\
\text { plebiscite. We construct a measure that indicates whether } \\
\text { a democratic chief assumed power via village elections or } \\
\text { referendum. }\end{array}$ & Village & CQ54 \\
\hline Exposure & $\begin{array}{l}\text { Between } 0 \text { and } 20 . \text { Number of years the village has } \\
\text { democratic rule during last two decades. In } 31 \text { cases we } \\
\text { did not have information about how the previous chief } \\
\text { obtained power. Excluding these villages provides the } \\
\text { same results. }\end{array}$ & Village & $\begin{array}{l}\text { CQ50, CQ53, } \\
\text { CQ54 }\end{array}$ \\
\hline Age & Continuous. In 10 years. & Individual & QF9 \\
\hline Male & Binary. Female is zero. Male is one. & Individual & QF7 \\
\hline Wealth & $\begin{array}{l}\text { We record whether walls are made of mud, plastic, non- } \\
\text { baked bricks, bamboo, stone, semi-durables, baked } \\
\text { bricks, concrete, metal, or cardboard. Multiple responses } \\
\text { are possible for any given household. We construct a } \\
\text { measure to indicate a high-quality wall to be a wall made } \\
\text { out of baked bricks, concrete, or metal. }\end{array}$ & Household & QE10 \\
\hline $\begin{array}{l}\text { Education household } \\
\text { head }\end{array}$ & Continuous in years. & Household & QF13 \\
\hline Distance health centre & $\begin{array}{l}\text { Continuous in hours. Walking distance (return) to a } \\
\text { health centre (dispensary / health post/ hospital), during } \\
\text { the rainy season. }\end{array}$ & Household & QE13F \\
\hline Health committee & Binary. Presence of a health committee in the village. & Village & CQ36 \\
\hline NGO exposure & $\begin{array}{l}\text { Binary. Presence of at least one NGO in the village } \\
\text { during the last four years. }\end{array}$ & Village & CQ31 \\
\hline Conflict exposure & $\begin{array}{l}\text { Binary. Whether villagers had to flee the village due to } \\
\text { conflict between } 2005 \text { and } 2010 \text {. }\end{array}$ & Village & CQ140 \\
\hline Ethnic heterogeneity & $\begin{array}{l}\text { Continuous between } 0 \text { and } 1 . \text { Measures the probability } \\
\text { that two randomly drawn individuals from the village } \\
\text { belong to different ethnic groups. Calculated as one } \\
\text { minus the sum of the squared shares of the ethnic groups. }\end{array}$ & Village & CQ13 \\
\hline Village isolation & $\begin{array}{l}\text { Continuous in hours. Walking distance (return) from the } \\
\text { nearest public transport facility, during the rainy season. }\end{array}$ & Village & QE13C \\
\hline
\end{tabular}

Notes: Question number responds to survey. Data and instruments are available online: [Redacted]. 


\section{Online Appendix: Replication of Table 1 by Village Type (chief elected or not)}

Table A2 replicates Table 1, where we separate out the summary information by village type (elected and not elected chief). The number of observations in Table 1 do not add up to the number of observations in Table A2, because of missing responses to the democracy variable.

Table A2. Descriptive Statistics

\begin{tabular}{|c|c|c|c|c|c|c|c|c|c|c|c|}
\hline & & & Chief I & ot ele & ted & & & Chis & f elect & & \\
\hline \# & Variable (unit) & $\mathbf{N}$ & Mean & SD & Min & $\operatorname{Max}$ & $\mathbf{N}$ & Mean & SD & Min & $\operatorname{Max}$ \\
\hline 1 & Severely ill & 21,825 & 0.18 & 0.38 & 0 & 1 & 7,749 & 0.17 & 0.37 & 0 & 1 \\
\hline 2 & Fever (children U7 only) & 6,639 & 0.31 & 0.46 & 0 & 1 & 2,364 & 0.31 & 0.46 & 0 & 1 \\
\hline 3 & Cough (children U7 only) & 6,645 & 0.26 & 0.44 & 0 & 1 & 2,362 & 0.27 & 0.44 & 0 & 1 \\
\hline 4 & Diarrhoea (children U7 only) & 6,575 & 0.09 & 0.29 & 0 & 1 & 2,339 & 0.10 & 0.30 & 0 & 1 \\
\hline 5 & Democracy & 22,854 & 0.00 & 0.00 & 0 & 0 & 8,038 & 1.00 & 0.00 & 1 & 1 \\
\hline 6 & Exposure & 22,568 & 0.70 & 3.17 & 0 & 19 & 8,038 & 13.56 & 7.31 & 0 & 20 \\
\hline 7 & Age (10 years) & 21,766 & 2.18 & 1.78 & 0.1 & 10.4 & 7,723 & 2.18 & 1.77 & 0.1 & 10.3 \\
\hline 8 & Male & 22,568 & 0.50 & 0.50 & 0 & 1 & 7,927 & 0.51 & 0.50 & 0 & 1 \\
\hline 9 & Wealth & 22,582 & 7.80 & 3.44 & 1 & 27 & 8,001 & 7.70 & 3.45 & 1 & 20 \\
\hline 10 & Education household head (years) & 22,371 & 0.07 & 0.26 & 0 & 1 & 7,811 & 0.09 & 0.29 & 0 & 1 \\
\hline 11 & Distance nearest health center (hours) & 17,711 & 4.21 & 3.35 & 0 & 15 & 5,999 & 5.11 & 3.59 & 0 & 15 \\
\hline 12 & Health committee & 19,950 & 2.35 & 5.94 & 0 & 96 & 7,067 & 1.55 & 3.41 & 0 & 48 \\
\hline 13 & NGO exposure & 22,825 & 0.57 & 0.49 & 0 & 1 & 8,038 & 0.49 & 0.50 & 0 & 1 \\
\hline 14 & Conflict exposure & 21,526 & 0.79 & 0.41 & 0 & 1 & 7,667 & 0.85 & 0.36 & 0 & 1 \\
\hline 15 & Ethnic heterogeneity & 22,320 & 1.28 & 7.77 & 0 & 120 & 7,848 & 1.65 & 7.65 & 0 & 83.3 \\
\hline 16 & Village isolation (hours) & 22,398 & 0.30 & 0.28 & 0 & 0.81 & 7,930 & 0.37 & 0.27 & 0 & 0.82 \\
\hline
\end{tabular}

Notes: Based on survey data. Variable details in Table A1. 
Table A3. Democracy and Health Outcomes (standard errors not clustered)

\begin{tabular}{|c|c|c|c|c|c|c|c|c|}
\hline & $\begin{array}{c}(1) \\
\text { Severely ill }\end{array}$ & $\begin{array}{c}(2) \\
\text { Fever }\end{array}$ & $\begin{array}{c}(3) \\
\text { Cough }\end{array}$ & $\begin{array}{c}(4) \\
\text { Diarrhoea }\end{array}$ & $\begin{array}{c}(5) \\
\text { Severely ill }\end{array}$ & $\begin{array}{c}(6) \\
\text { Fever }\end{array}$ & $\begin{array}{c}(7) \\
\text { Cough }\end{array}$ & $\begin{array}{c}(8) \\
\text { Diarrhoea }\end{array}$ \\
\hline Democracy & $\begin{array}{l}-0.013^{*} \\
(0.007)\end{array}$ & $\begin{array}{l}-0.012 \\
(0.015)\end{array}$ & $\begin{array}{c}-0.001 \\
(0.014)\end{array}$ & $\begin{array}{c}0.002 \\
(0.009)\end{array}$ & & & & \\
\hline Exposure & & & & & $\begin{array}{c}-0.001^{* *} \\
(0.000)\end{array}$ & $\begin{array}{l}-0.000 \\
(0.001) \\
\end{array}$ & $\begin{array}{c}0.001 \\
(0.001) \\
\end{array}$ & $\begin{array}{c}-0.000 \\
(0.001) \\
\end{array}$ \\
\hline Male & $\begin{array}{c}-0.046^{* * *} \\
(0.006)\end{array}$ & $\begin{array}{l}-0.023^{*} \\
(0.012)\end{array}$ & $\begin{array}{l}-0.021^{*} \\
(0.012)\end{array}$ & $\begin{array}{l}-0.015^{* *} \\
(0.008)\end{array}$ & $\begin{array}{c}-0.045^{* * *} \\
(0.006)\end{array}$ & $\begin{array}{c}-0.024^{* *} \\
(0.012)\end{array}$ & $\begin{array}{c}-0.023^{* *} \\
(0.011)\end{array}$ & $\begin{array}{l}-0.015^{* *} \\
(0.008)\end{array}$ \\
\hline Age & $\begin{array}{c}0.007 \\
(0.005)\end{array}$ & $\begin{array}{c}0.070 \\
(0.110)\end{array}$ & $\begin{array}{l}-0.090 \\
(0.106)\end{array}$ & $\begin{array}{c}-0.281^{* * * *} \\
(0.067)\end{array}$ & $\begin{array}{c}0.006 \\
(0.005)\end{array}$ & $\begin{array}{c}0.086 \\
(0.109)\end{array}$ & $\begin{array}{l}-0.043 \\
(0.105)\end{array}$ & $\begin{array}{c}-0.285^{* * * *} \\
(0.067)\end{array}$ \\
\hline $\mathrm{Age}^{2}$ & $\begin{array}{l}0.003^{* * * *} \\
(0.001)\end{array}$ & $\begin{array}{c}-0.275^{* *} \\
(0.107)\end{array}$ & $\begin{array}{l}-0.123 \\
(0.103)\end{array}$ & $\begin{array}{c}0.117^{*} \\
(0.068)\end{array}$ & $\begin{array}{l}0.004^{* * * *} \\
(0.001)\end{array}$ & $\begin{array}{c}-0.297^{* * *} \\
(0.106)\end{array}$ & $\begin{array}{l}-0.174^{*} \\
(0.103)\end{array}$ & $\begin{array}{c}0.118^{*} \\
(0.067)\end{array}$ \\
\hline Education & $\begin{array}{c}-0.003^{* * *} \\
(0.001)\end{array}$ & $\begin{array}{c}-0.007^{* * *} \\
(0.002)\end{array}$ & $\begin{array}{l}-0.004^{*} \\
(0.002)\end{array}$ & $\begin{array}{c}-0.004^{* * * *} \\
(0.001)\end{array}$ & $\begin{array}{c}-0.003^{* * *} \\
(0.001)\end{array}$ & $\begin{array}{c}-0.007^{* * * *} \\
(0.002)\end{array}$ & $\begin{array}{l}-0.003^{*} \\
(0.002)\end{array}$ & $\begin{array}{c}-0.004^{* * *} \\
(0.001)\end{array}$ \\
\hline Wealth & $\begin{array}{l}-0.021^{*} \\
(0.011)\end{array}$ & $\begin{array}{l}-0.014 \\
(0.024)\end{array}$ & $\begin{array}{l}-0.017 \\
(0.023)\end{array}$ & $\begin{array}{c}0.007 \\
(0.015)\end{array}$ & $\begin{array}{l}-0.021^{*} \\
(0.011)\end{array}$ & $\begin{array}{l}-0.017 \\
(0.024)\end{array}$ & $\begin{array}{l}-0.019 \\
(0.023)\end{array}$ & $\begin{array}{c}0.005 \\
(0.015)\end{array}$ \\
\hline Distance & $\begin{array}{l}-0.001^{*} \\
(0.001)\end{array}$ & $\begin{array}{l}0.003^{* *} \\
(0.001)\end{array}$ & $\begin{array}{c}0.003^{* * *} \\
(0.001)\end{array}$ & $\begin{array}{l}-0.000 \\
(0.001)\end{array}$ & $\begin{array}{c}-0.001^{* *} \\
(0.001)\end{array}$ & $\begin{array}{l}0.003^{* *} \\
(0.001)\end{array}$ & $\begin{array}{l}0.003^{* *} \\
(0.001)\end{array}$ & $\begin{array}{l}-0.000 \\
(0.001)\end{array}$ \\
\hline Committee & $\begin{array}{l}-0.005 \\
(0.006)\end{array}$ & $\begin{array}{l}-0.010 \\
(0.014)\end{array}$ & $\begin{array}{c}0.012 \\
(0.013)\end{array}$ & $\begin{array}{c}0.004 \\
(0.009)\end{array}$ & $\begin{array}{l}-0.004 \\
(0.006)\end{array}$ & $\begin{array}{l}-0.011 \\
(0.014)\end{array}$ & $\begin{array}{c}0.010 \\
(0.013)\end{array}$ & $\begin{array}{c}0.003 \\
(0.009)\end{array}$ \\
\hline NGO & $\begin{array}{c}0.000 \\
(0.007)\end{array}$ & $\begin{array}{c}0.024 \\
(0.016)\end{array}$ & $\begin{array}{c}0.013 \\
(0.015)\end{array}$ & $\begin{array}{l}-0.002 \\
(0.010)\end{array}$ & $\begin{array}{l}-0.002 \\
(0.007)\end{array}$ & $\begin{array}{c}0.020 \\
(0.016)\end{array}$ & $\begin{array}{c}0.011 \\
(0.015)\end{array}$ & $\begin{array}{l}-0.002 \\
(0.010)\end{array}$ \\
\hline Conflict & $\begin{array}{l}-0.000 \\
(0.000)\end{array}$ & $\begin{array}{c}0.001^{*} \\
(0.001)\end{array}$ & $\begin{array}{l}0.001^{*} \\
(0.001)\end{array}$ & $\begin{array}{c}0.000 \\
(0.001)\end{array}$ & $\begin{array}{c}0.000 \\
(0.000)\end{array}$ & $\begin{array}{c}0.001^{*} \\
(0.001)\end{array}$ & $\begin{array}{c}0.001^{*} \\
(0.001)\end{array}$ & $\begin{array}{c}0.000 \\
(0.001)\end{array}$ \\
\hline Ethnic & $\begin{array}{l}-0.002 \\
(0.014)\end{array}$ & $\begin{array}{c}0.095^{* * *} \\
(0.030)\end{array}$ & $\begin{array}{c}0.030 \\
(0.029)\end{array}$ & $\begin{array}{c}0.012 \\
(0.019)\end{array}$ & $\begin{array}{l}-0.004 \\
(0.014)\end{array}$ & $\begin{array}{c}0.098^{* * *} \\
(0.030)\end{array}$ & $\begin{array}{c}0.032 \\
(0.029)\end{array}$ & $\begin{array}{c}0.015 \\
(0.019)\end{array}$ \\
\hline Isolation & $\begin{array}{c}-0.001^{* * *} \\
(0.000)\end{array}$ & $\begin{array}{c}-0.002^{* * *} \\
(0.001)\end{array}$ & $\begin{array}{c}-0.002^{* * *} \\
(0.001)\end{array}$ & $\begin{array}{l}-0.001^{* * *} \\
(0.000)\end{array}$ & $\begin{array}{c}-0.001^{* * *} \\
(0.000)\end{array}$ & $\begin{array}{c}-0.002^{* * *} \\
(0.001)\end{array}$ & $\begin{array}{c}-0.002^{* * *} \\
(0.001)\end{array}$ & $\begin{array}{l}-0.001^{*} \\
(0.000)\end{array}$ \\
\hline FEs & $Y$ & $\mathrm{Y}$ & $\mathrm{Y}$ & $\mathrm{Y}$ & $\mathrm{Y}$ & $\mathrm{Y}$ & $\mathrm{Y}$ & $\mathrm{Y}$ \\
\hline Sample & All & U7 & U7 & $\mathrm{U} 7$ & All & U7 & U7 & $\mathrm{U} 7$ \\
\hline Kingdoms & 55 & 55 & 55 & 55 & 55 & 55 & 55 & 55 \\
\hline $\mathrm{N}$ & 17,611 & 5,701 & 5,703 & 5,626 & 17,768 & 5,752 & 5,754 & 5,679 \\
\hline
\end{tabular}

Notes: Marginal effects from probit regressions with kingdom fixed effects. Standard errors in parentheses. ${ }^{*} \mathrm{p}<0.10,{ }^{* *} \mathrm{p}<0.05,{ }^{* * *} \mathrm{p}<0.01$. 


\section{Online Appendix: Robustness Test. Panel Analysis}

A total of 942 households (6,056 individuals), in 286 villages, were visited in 2007 that we aimed to visit in 2012. We were able to revisit 219 villages, and 627 households. The same data were collected in 2007 and 2012, with the exception of information about the health committee and conflict exposure. Table A3 presents descriptive information separated out by year, where we aggregate (average) health outcomes, age and gender at the household level. For those regressions related to flu, cough, and diarrhoea, we aggregate age and gender only for those children below the age of seven. Next, Table A4 shows the relationship between democracy and exposure to democracy and health outcomes using this panel data.

Table A4. Additional Descriptive Statistics. Household Level

\begin{tabular}{|c|c|c|c|c|c|c|}
\hline$\#$ & Variable (unit) & $\mathbf{N}$ & Mean & SD & Min & Max \\
\hline \multicolumn{7}{|c|}{ Year $=2012$} \\
\hline 1 & Severely ill & 670 & 0.218 & 0.262 & 0 & 1 \\
\hline 2 & Fever (children U7 only) & 481 & 0.286 & 0.359 & 0 & 1 \\
\hline 3 & Cough (children U7 only) & 481 & 0.249 & 0.348 & 0 & 1 \\
\hline 4 & Diarrhoea (children U7 only) & 480 & 0.089 & 0.216 & 0 & 1 \\
\hline 5 & Democracy & 656 & 0.270 & 0.444 & 0 & 1 \\
\hline 6 & Exposure & 662 & 4.128 & 7.220 & 0 & 20 \\
\hline 7 & Average age ( 10 years $)$ & 668 & 2.511 & 1.349 & 0.32 & 10.4 \\
\hline 8 & Average age children (10 years) & 450 & 0.408 & 0.128 & 0.1 & 0.7 \\
\hline 9 & Share Males & 670 & 0.494 & 0.196 & 0 & 1 \\
\hline 10 & Share Boys & 450 & 0.480 & 0.377 & 0 & 1 \\
\hline 11 & Wealth & 670 & 0.099 & 0.298 & 0 & 1 \\
\hline 12 & Education household head (years) & 498 & 5.396 & 3.766 & 0 & 15 \\
\hline 13 & Distance nearest health center (hours) & 621 & 1.792 & 4.949 & 0 & 96 \\
\hline 14 & NGO exposure & 625 & 0.629 & 0.484 & 0 & 1 \\
\hline 15 & Ethnic heterogeneity & 665 & 0.343 & 0.282 & 0 & 0.805 \\
\hline 16 & Village isolation (hours) & 627 & 3.231 & 9.572 & 0 & 130 \\
\hline \multicolumn{7}{|c|}{ Year $=2007$} \\
\hline 16 & Severely ill & 933 & 0.116 & 0.195 & 0 & 1 \\
\hline 17 & Flu (children U7 only) & 580 & 0.275 & 0.397 & 0 & 1 \\
\hline 18 & Cough (children U7 only) & 578 & 0.218 & 0.368 & 0 & 1 \\
\hline 19 & Diarrhoea (children U7 only) & 575 & 0.114 & 0.272 & 0 & 1 \\
\hline 20 & Democracy & 730 & 0.312 & 0.464 & 0 & 1 \\
\hline 21 & Exposure & 790 & 4.841 & 7.744 & 0 & 20 \\
\hline 22 & Average age (10 years) & 908 & 2.335 & 1.056 & 0.1 & 7.8 \\
\hline 23 & Average age children (10 years) & 614 & 0.361 & 0.178 & 0 & 0.7 \\
\hline 24 & Share Males & 942 & 0.506 & 0.166 & 0 & 1 \\
\hline 25 & Share Boys & 613 & 0.475 & 0.386 & 0 & 1 \\
\hline 26 & Wealth & 881 & 0.059 & 0.236 & 0 & 1 \\
\hline 27 & Education household head (years) & 552 & 2.506 & 1.856 & 0 & 9.7 \\
\hline 28 & Distance nearest health center (hours) & 871 & 1.835 & 4.094 & 0 & 52 \\
\hline 29 & NGO exposure & 778 & 0.550 & 0.498 & 0 & 1 \\
\hline 30 & Ethnic heterogeneity & 878 & 0.290 & 0.260 & 0 & 0.975 \\
\hline 31 & Village isolation (hours) & 935 & 4.910 & 7.842 & 0 & 48 \\
\hline
\end{tabular}

Notes: Survey questions: QF21; QF20; CQ54; CQ53; QF9; QF7; QE10; QE13f; CQ31; CQ13; QE13c (for 2012), and Q32; Q31; Q20; Q18; Q24; Q23; Q44; Q58f; Q58c; CQ34; CQ28; CQ33b; CQ68n; CQ17 (for 2007). 
Table A5 shows the relationship between democracy and exposure to democracy, and health outcomes.

Table A5. Democracy and Health Outcomes: Panel

\begin{tabular}{|c|c|c|c|c|c|c|c|c|}
\hline & $\begin{array}{c}(1) \\
\text { Severely ill }\end{array}$ & $\begin{array}{c}(2) \\
\text { Fever }\end{array}$ & $\begin{array}{c}(3) \\
\text { Cough }\end{array}$ & $\begin{array}{c}(4) \\
\text { Diarrhoea }\end{array}$ & $\begin{array}{c}(5) \\
\text { Severely ill }\end{array}$ & $\begin{array}{c}(6) \\
\text { Fever }\end{array}$ & $\begin{array}{c}(7) \\
\text { Cough }\end{array}$ & $\begin{array}{c}(8) \\
\text { Diarrhoea }\end{array}$ \\
\hline Democracy & $\begin{array}{l}-0.017 \\
(0.020)\end{array}$ & $\begin{array}{c}0.005 \\
(0.040)\end{array}$ & $\begin{array}{c}0.017 \\
(0.041)\end{array}$ & $\begin{array}{l}-0.013 \\
(0.030)\end{array}$ & & & & \\
\hline Exposure & & & & & $\begin{array}{c}0.000 \\
(0.001) \\
\end{array}$ & $\begin{array}{c}0.004 \\
(0.002) \\
\end{array}$ & $\begin{array}{c}0.005^{*} \\
(0.003) \\
\end{array}$ & $\begin{array}{c}-0.001 \\
(0.002) \\
\end{array}$ \\
\hline Male & $\begin{array}{l}-0.016 \\
(0.069)\end{array}$ & $\begin{array}{c}0.008 \\
(0.050)\end{array}$ & $\begin{array}{c}0.053 \\
(0.049)\end{array}$ & $\begin{array}{c}0.014 \\
(0.038)\end{array}$ & $\begin{array}{l}-0.020 \\
(0.067)\end{array}$ & $\begin{array}{l}-0.006 \\
(0.050)\end{array}$ & $\begin{array}{c}0.042 \\
(0.049)\end{array}$ & $\begin{array}{c}0.002 \\
(0.038)\end{array}$ \\
\hline Age & $\begin{array}{l}-0.023 \\
(0.042)\end{array}$ & $\begin{array}{l}1.108^{* *} \\
(0.503)\end{array}$ & $\begin{array}{l}0.953^{* *} \\
(0.481)\end{array}$ & $\begin{array}{c}0.391 \\
(0.429)\end{array}$ & $\begin{array}{l}-0.026 \\
(0.041)\end{array}$ & $\begin{array}{l}1.185^{* *} \\
(0.509)\end{array}$ & $\begin{array}{l}0.963^{* *} \\
(0.487)\end{array}$ & $\begin{array}{c}0.443 \\
(0.428)\end{array}$ \\
\hline $\mathrm{Age}^{2}$ & $\begin{array}{c}0.006 \\
(0.006)\end{array}$ & $\begin{array}{c}-1.431^{* *} \\
(0.629)\end{array}$ & $\begin{array}{c}-1.487^{* *} \\
(0.610)\end{array}$ & $\begin{array}{l}-0.707 \\
(0.493)\end{array}$ & $\begin{array}{c}0.006 \\
(0.006)\end{array}$ & $\begin{array}{c}-1.586^{* *} \\
(0.634)\end{array}$ & $\begin{array}{l}-1.571^{* *} \\
(0.615)\end{array}$ & $\begin{array}{l}-0.762 \\
(0.492)\end{array}$ \\
\hline Education & $\begin{array}{l}-0.000 \\
(0.002)\end{array}$ & $\begin{array}{c}-0.014^{* *} \\
(0.005)\end{array}$ & $\begin{array}{l}-0.003 \\
(0.005)\end{array}$ & $\begin{array}{c}-0.008^{* * *} \\
(0.003)\end{array}$ & $\begin{array}{l}-0.000 \\
(0.002)\end{array}$ & $\begin{array}{c}-0.012^{* *} \\
(0.005)\end{array}$ & $\begin{array}{l}-0.003 \\
(0.005)\end{array}$ & $\begin{array}{c}-0.005 \\
(0.004)\end{array}$ \\
\hline Wealth & $\begin{array}{l}-0.026 \\
(0.034)\end{array}$ & $\begin{array}{l}-0.005 \\
(0.055)\end{array}$ & $\begin{array}{c}0.053 \\
(0.057)\end{array}$ & $\begin{array}{c}0.025 \\
(0.039)\end{array}$ & $\begin{array}{l}-0.029 \\
(0.034)\end{array}$ & $\begin{array}{l}-0.025 \\
(0.055)\end{array}$ & $\begin{array}{c}0.037 \\
(0.058)\end{array}$ & $\begin{array}{c}0.017 \\
(0.039)\end{array}$ \\
\hline Distance & $\begin{array}{l}-0.004^{*} \\
(0.002)\end{array}$ & $\begin{array}{c}-0.002 \\
(0.003)\end{array}$ & $\begin{array}{l}-0.003 \\
(0.003)\end{array}$ & $\begin{array}{l}-0.002 \\
(0.003)\end{array}$ & $\begin{array}{l}-0.004^{*} \\
(0.002)\end{array}$ & $\begin{array}{c}-0.002 \\
(0.003)\end{array}$ & $\begin{array}{l}-0.003 \\
(0.003)\end{array}$ & $\begin{array}{c}-0.002 \\
(0.003)\end{array}$ \\
\hline NGO & $\begin{array}{l}0.036^{*} \\
(0.020)\end{array}$ & $\begin{array}{c}0.074^{*} \\
(0.039)\end{array}$ & $\begin{array}{c}0.040 \\
(0.035)\end{array}$ & $\begin{array}{c}0.012 \\
(0.026)\end{array}$ & $\begin{array}{l}0.039^{* *} \\
(0.019)\end{array}$ & $\begin{array}{c}0.071^{*} \\
(0.039)\end{array}$ & $\begin{array}{c}0.031 \\
(0.035)\end{array}$ & $\begin{array}{c}0.018 \\
(0.026)\end{array}$ \\
\hline Ethnic & $\begin{array}{c}0.006 \\
(0.038)\end{array}$ & $\begin{array}{c}0.085 \\
(0.073)\end{array}$ & $\begin{array}{c}0.006 \\
(0.070)\end{array}$ & $\begin{array}{c}0.053 \\
(0.048)\end{array}$ & $\begin{array}{c}0.007 \\
(0.038)\end{array}$ & $\begin{array}{c}0.087 \\
(0.073)\end{array}$ & $\begin{array}{c}0.003 \\
(0.070)\end{array}$ & $\begin{array}{c}0.049 \\
(0.047)\end{array}$ \\
\hline Isolation & $\begin{array}{c}0.000 \\
(0.000)\end{array}$ & $\begin{array}{c}0.000 \\
(0.002)\end{array}$ & $\begin{array}{l}-0.001 \\
(0.001)\end{array}$ & $\begin{array}{c}0.001 \\
(0.001)\end{array}$ & $\begin{array}{c}0.000 \\
(0.001)\end{array}$ & $\begin{array}{c}0.000 \\
(0.002)\end{array}$ & $\begin{array}{l}-0.001 \\
(0.001)\end{array}$ & $\begin{array}{c}0.001 \\
(0.001)\end{array}$ \\
\hline Constant & $\begin{array}{c}0.167^{* * * *} \\
(0.061)\end{array}$ & $\begin{array}{c}0.115 \\
(0.079)\end{array}$ & $\begin{array}{l}0.124^{*} \\
(0.075)\end{array}$ & $\begin{array}{c}0.107 \\
(0.075)\end{array}$ & $\begin{array}{c}0.163^{* * * *} \\
(0.060)\end{array}$ & $\begin{array}{c}0.114 \\
(0.080)\end{array}$ & $\begin{array}{c}0.137^{*} \\
(0.076)\end{array}$ & $\begin{array}{c}0.092 \\
(0.075)\end{array}$ \\
\hline Random Effects & $\mathrm{Y}$ & $\mathrm{Y}$ & $\mathrm{Y}$ & $\mathrm{Y}$ & $\mathrm{Y}$ & $\mathrm{Y}$ & $\mathrm{Y}$ & $\mathrm{Y}$ \\
\hline Sample & All & U7 & U7 & U7 & All & U7 & U7 & U7 \\
\hline $\mathrm{N}$ & 669 & 447 & 446 & 443 & 693 & 461 & 460 & 458 \\
\hline
\end{tabular}

Notes: Table reports result from a panel regression with random effects. Standard errors (clustered at the village level) in parentheses. ${ }^{*} \mathrm{p}<0.10,{ }^{* *} \mathrm{p}<0.05,{ }^{* * *} \mathrm{p}<0.01$. 


\section{Online Appendix: Robustness Test. Institutional Characteristics}

This section explores the relationship between democracy and health, using different definitions of democracy. Table A6 provides descriptive information on the variables used for this robustness check. Next, Tables A7-A9 provide results where the explanatory variable is whether the chief inherited their position, whether they were chosen by actors from outside the village, whether the previous chief was elected, whether the village changed in being governed by a not-democratically elected chief to a democratically elected chief, whether the chief is educated (in years of education), and whether they are literate, respectively.

Table A6. Additional Descriptive Statistics

\begin{tabular}{llccccc}
\hline$\#$ & Variable (unit) & N & Mean & SD & Min & Max \\
\hline 1 & Chief Inherited & 30,892 & 0.383 & 0.486 & 0 & 1 \\
2 & Chief Outside & 30,892 & 0.230 & 0.421 & 0 & 1 \\
3 & Previous Chief & 28,854 & 0.166 & 0.372 & 0 & 1 \\
4 & Change to Democracy & 28,369 & 0.125 & 0.330 & 0 & 1 \\
5 & Chief Educated & 21,999 & 6.335 & 3.464 & 0 & 15 \\
6 & Chief Literate & 31,362 & 0.863 & 0.344 & 0 & 1 \\
\hline
\end{tabular}

Notes: Based on survey questions: CQ54; CQ48; QF13; QF12. 
Table A7 provides results from regressing health outcomes on whether the chief inherited their position, and whether they were chosen by actors from outside the village.

Table A7. Democracy and Health Outcomes: Chief Inherited and Chief Outside

\begin{tabular}{|c|c|c|c|c|c|c|c|c|}
\hline & $\begin{array}{c}(1) \\
\text { Severely ill }\end{array}$ & $\begin{array}{c}(2) \\
\text { Fever }\end{array}$ & $\begin{array}{c}\text { (3) } \\
\text { Cough }\end{array}$ & $\begin{array}{c}(4) \\
\text { Diarrhoea }\end{array}$ & $\begin{array}{c}(5) \\
\text { Severely ill }\end{array}$ & $\begin{array}{c}(6) \\
\text { Fever }\end{array}$ & $\begin{array}{c}(7) \\
\text { Cough }\end{array}$ & $\begin{array}{c}(8) \\
\text { Diarrhoea }\end{array}$ \\
\hline Chief Inherited & $\begin{array}{l}-0.005 \\
(0.013)\end{array}$ & $\begin{array}{l}-0.001 \\
(0.020)\end{array}$ & $\begin{array}{l}-0.009 \\
(0.021)\end{array}$ & $\begin{array}{c}0.013 \\
(0.011)\end{array}$ & & & & \\
\hline Chief Outside & & & & & $\begin{array}{c}0.010 \\
(0.013)\end{array}$ & $\begin{array}{c}0.006 \\
(0.021)\end{array}$ & $\begin{array}{c}-0.007 \\
(0.023)\end{array}$ & $\begin{array}{c}-0.013 \\
(0.011)\end{array}$ \\
\hline Male & $\begin{array}{c}-0.046^{* * * *} \\
(0.005)\end{array}$ & $\begin{array}{l}-0.023^{*} \\
(0.012)\end{array}$ & $\begin{array}{l}-0.021^{*} \\
(0.012)\end{array}$ & $\begin{array}{c}-0.015^{* *} \\
(0.008)\end{array}$ & $\begin{array}{c}-0.046^{* * * *} \\
(0.005)\end{array}$ & $\begin{array}{l}-0.023^{*} \\
(0.012)\end{array}$ & $\begin{array}{l}-0.021^{*} \\
(0.012)\end{array}$ & $\begin{array}{c}-0.015^{* * *} \\
(0.008)\end{array}$ \\
\hline Age & $\begin{array}{c}0.007 \\
(0.006)\end{array}$ & $\begin{array}{c}0.069 \\
(0.106)\end{array}$ & $\begin{array}{l}-0.089 \\
(0.099)\end{array}$ & $\begin{array}{c}-0.281^{* * * *} \\
(0.065)\end{array}$ & $\begin{array}{c}0.007 \\
(0.006)\end{array}$ & $\begin{array}{c}0.070 \\
(0.106)\end{array}$ & $\begin{array}{c}-0.090 \\
(0.099)\end{array}$ & $\begin{array}{c}-0.282^{* * *} \\
(0.065)\end{array}$ \\
\hline $\mathrm{Age}^{2}$ & $\begin{array}{l}0.003^{* * *} \\
(0.001)\end{array}$ & $\begin{array}{c}-0.274^{* * *} \\
(0.101)\end{array}$ & $\begin{array}{c}-0.124 \\
(0.094)\end{array}$ & $\begin{array}{c}0.118^{*} \\
(0.065)\end{array}$ & $\begin{array}{l}0.003^{* * *} \\
(0.001)\end{array}$ & $\begin{array}{c}-0.274^{* * *} \\
(0.101)\end{array}$ & $\begin{array}{l}-0.123 \\
(0.094)\end{array}$ & $\begin{array}{c}0.118^{*} \\
(0.065)\end{array}$ \\
\hline Education & $\begin{array}{c}-0.003^{* *} \\
(0.001)\end{array}$ & $\begin{array}{c}-0.008^{* * * *} \\
(0.002)\end{array}$ & $\begin{array}{l}-0.004 \\
(0.002)\end{array}$ & $\begin{array}{c}-0.004^{* * * *} \\
(0.001)\end{array}$ & $\begin{array}{c}-0.003^{* *} \\
(0.001)\end{array}$ & $\begin{array}{c}-0.007^{* * *} \\
(0.002)\end{array}$ & $\begin{array}{c}-0.004 \\
(0.002)\end{array}$ & $\begin{array}{c}-0.004^{* * *} \\
(0.001)\end{array}$ \\
\hline Wealth & $\begin{array}{l}-0.022 \\
(0.017)\end{array}$ & $\begin{array}{l}-0.016 \\
(0.031)\end{array}$ & $\begin{array}{l}-0.017 \\
(0.029)\end{array}$ & $\begin{array}{c}0.007 \\
(0.019)\end{array}$ & $\begin{array}{l}-0.022 \\
(0.017)\end{array}$ & $\begin{array}{l}-0.015 \\
(0.031)\end{array}$ & $\begin{array}{l}-0.017 \\
(0.029)\end{array}$ & $\begin{array}{c}0.006 \\
(0.019)\end{array}$ \\
\hline Distance & $\begin{array}{l}-0.001 \\
(0.001)\end{array}$ & $\begin{array}{l}0.003^{* * *} \\
(0.002)\end{array}$ & $\begin{array}{l}0.003^{* *} \\
(0.002)\end{array}$ & $\begin{array}{l}-0.000 \\
(0.001)\end{array}$ & $\begin{array}{l}-0.001 \\
(0.001)\end{array}$ & $\begin{array}{l}0.003^{* *} \\
(0.002)\end{array}$ & $\begin{array}{l}0.003^{* * *} \\
(0.002)\end{array}$ & $\begin{array}{l}-0.000 \\
(0.001)\end{array}$ \\
\hline Committee & $\begin{array}{l}-0.004 \\
(0.012)\end{array}$ & $\begin{array}{l}-0.009 \\
(0.019)\end{array}$ & $\begin{array}{c}0.012 \\
(0.021)\end{array}$ & $\begin{array}{c}0.003 \\
(0.010)\end{array}$ & $\begin{array}{l}-0.004 \\
(0.012)\end{array}$ & $\begin{array}{l}-0.009 \\
(0.019)\end{array}$ & $\begin{array}{c}0.012 \\
(0.021)\end{array}$ & $\begin{array}{c}0.004 \\
(0.010)\end{array}$ \\
\hline NGO & $\begin{array}{l}-0.001 \\
(0.015)\end{array}$ & $\begin{array}{c}0.023 \\
(0.025)\end{array}$ & $\begin{array}{c}0.013 \\
(0.026)\end{array}$ & $\begin{array}{l}-0.002 \\
(0.013)\end{array}$ & $\begin{array}{l}-0.000 \\
(0.015)\end{array}$ & $\begin{array}{c}0.024 \\
(0.025)\end{array}$ & $\begin{array}{c}0.012 \\
(0.027)\end{array}$ & $\begin{array}{l}-0.004 \\
(0.013)\end{array}$ \\
\hline Conflict & $\begin{array}{l}-0.000 \\
(0.001)\end{array}$ & $\begin{array}{l}0.001^{*} \\
(0.001)\end{array}$ & $\begin{array}{l}0.001^{*} \\
(0.001)\end{array}$ & $\begin{array}{c}0.000 \\
(0.000)\end{array}$ & $\begin{array}{l}-0.000 \\
(0.001)\end{array}$ & $\begin{array}{l}0.001^{*} \\
(0.001)\end{array}$ & $\begin{array}{c}0.001^{*} \\
(0.001)\end{array}$ & $\begin{array}{c}0.000 \\
(0.001)\end{array}$ \\
\hline Ethnic & $\begin{array}{l}-0.003 \\
(0.026)\end{array}$ & $\begin{array}{l}0.095^{* * *} \\
(0.044)\end{array}$ & $\begin{array}{c}0.028 \\
(0.046)\end{array}$ & $\begin{array}{c}0.015 \\
(0.023)\end{array}$ & $\begin{array}{l}-0.002 \\
(0.025)\end{array}$ & $\begin{array}{l}0.095^{* *} \\
(0.043)\end{array}$ & $\begin{array}{c}0.030 \\
(0.046)\end{array}$ & $\begin{array}{c}0.012 \\
(0.023)\end{array}$ \\
\hline Isolation & $\begin{array}{c}-0.001^{* *} \\
(0.001)\end{array}$ & $\begin{array}{c}-0.002^{* * * *} \\
(0.001)\end{array}$ & $\begin{array}{c}-0.002^{* *} \\
(0.001)\end{array}$ & $\begin{array}{c}-0.001^{* * *} \\
(0.000)\end{array}$ & $\begin{array}{c}-0.001^{* *} \\
(0.001)\end{array}$ & $\begin{array}{c}-0.002^{* * *} \\
(0.001)\end{array}$ & $\begin{array}{c}-0.002^{* *} \\
(0.001)\end{array}$ & $\begin{array}{c}-0.001^{* *} \\
(0.000)\end{array}$ \\
\hline FEs & $\mathrm{Y}$ & $\mathrm{Y}$ & $\mathrm{Y}$ & $\mathrm{Y}$ & $\mathrm{Y}$ & $\mathrm{Y}$ & $\mathrm{Y}$ & $\mathrm{Y}$ \\
\hline Sample & All & U7 & U7 & U7 & All & U7 & U7 & U7 \\
\hline Kingdoms & 55 & 55 & 55 & 55 & 55 & 55 & 55 & 55 \\
\hline $\mathrm{N}$ & 17,611 & 5,701 & 5,703 & 5,626 & 17,611 & 5,701 & 5,703 & 5,626 \\
\hline
\end{tabular}

Notes: Table reports marginal effects from probit regressions with kingdom fixed effects, evaluated at the mean of the independent variables. Standard errors (clustered at the village level) in parentheses. * $\mathrm{p}<0.10, * * \mathrm{p}<0.05, * * * \mathrm{p}<0.01$. 
Table A8 provides results from regressing health outcomes on whether the previous chief was democratically elected, and whether the village changed in being governed by a not-democratically elected chief to a democratically elected chief.

Table A8. Democracy and Health Outcomes: Previous Chief and Change to Democracy

\begin{tabular}{|c|c|c|c|c|c|c|c|c|}
\hline & $\begin{array}{c}(1) \\
\text { Severely ill }\end{array}$ & $\begin{array}{c}(2) \\
\text { Fever }\end{array}$ & $\begin{array}{c}(3) \\
\text { Cough }\end{array}$ & $\begin{array}{c}(4) \\
\text { Diarrhoea }\end{array}$ & $\begin{array}{c}(5) \\
\text { Severely ill }\end{array}$ & $\begin{array}{c}(6) \\
\text { Fever }\end{array}$ & $\begin{array}{c}(7) \\
\text { Cough }\end{array}$ & $\begin{array}{c}(8) \\
\text { Diarrhoea }\end{array}$ \\
\hline Previous Chief & $\begin{array}{l}-0.005 \\
(0.013)\end{array}$ & $\begin{array}{c}0.011 \\
(0.021)\end{array}$ & $\begin{array}{c}0.023 \\
(0.025)\end{array}$ & $\begin{array}{l}-0.002 \\
(0.013)\end{array}$ & & & & \\
\hline Change to Demo. & & & & & $\begin{array}{c}-0.039^{* *} \\
(0.016)\end{array}$ & $\begin{array}{l}-0.034 \\
(0.034)\end{array}$ & $\begin{array}{l}-0.024 \\
(0.033)\end{array}$ & $\begin{array}{l}-0.000 \\
(0.015)\end{array}$ \\
\hline Male & $\begin{array}{c}-0.045^{* * *} \\
(0.006)\end{array}$ & $\begin{array}{l}-0.022^{*} \\
(0.013)\end{array}$ & $\begin{array}{l}-0.022^{*} \\
(0.012)\end{array}$ & $\begin{array}{c}-0.016^{* *} \\
(0.008)\end{array}$ & $\begin{array}{c}-0.046^{* * *} \\
(0.006)\end{array}$ & $\begin{array}{l}-0.022^{*} \\
(0.013)\end{array}$ & $\begin{array}{l}-0.021^{*} \\
(0.012)\end{array}$ & $\begin{array}{c}-0.016^{* *} \\
(0.008)\end{array}$ \\
\hline Age & $\begin{array}{c}0.004 \\
(0.006)\end{array}$ & $\begin{array}{c}0.076 \\
(0.113)\end{array}$ & $\begin{array}{c}-0.014 \\
(0.105)\end{array}$ & $\begin{array}{c}-0.274^{* * *} \\
(0.067)\end{array}$ & $\begin{array}{c}0.006 \\
(0.006)\end{array}$ & $\begin{array}{c}0.062 \\
(0.115)\end{array}$ & $\begin{array}{l}-0.045 \\
(0.105)\end{array}$ & $\begin{array}{c}-0.277^{* * *} \\
(0.068)\end{array}$ \\
\hline $\mathrm{Age}^{2}$ & $\begin{array}{l}0.004^{* * *} \\
(0.001)\end{array}$ & $\begin{array}{c}-0.292^{* * *} \\
(0.108)\end{array}$ & $\begin{array}{l}-0.205^{* *} \\
(0.100)\end{array}$ & $\begin{array}{c}0.102 \\
(0.067)\end{array}$ & $\begin{array}{l}0.003^{* * *} \\
(0.001)\end{array}$ & $\begin{array}{c}-0.274^{* *} \\
(0.110)\end{array}$ & $\begin{array}{l}-0.173^{*} \\
(0.100)\end{array}$ & $\begin{array}{c}0.107 \\
(0.068)\end{array}$ \\
\hline Education & $\begin{array}{c}-0.003^{* *} \\
(0.001)\end{array}$ & $\begin{array}{c}-0.007^{* * *} \\
(0.003)\end{array}$ & $\begin{array}{c}-0.003 \\
(0.002)\end{array}$ & $\begin{array}{c}-0.004^{* * * *} \\
(0.001)\end{array}$ & $\begin{array}{c}-0.003^{* *} \\
(0.001)\end{array}$ & $\begin{array}{c}-0.008^{* * *} \\
(0.003)\end{array}$ & $\begin{array}{l}-0.003 \\
(0.002)\end{array}$ & $\begin{array}{c}-0.004^{* * *} \\
(0.001)\end{array}$ \\
\hline Wealth & $\begin{array}{l}-0.019 \\
(0.018)\end{array}$ & $\begin{array}{l}-0.010 \\
(0.033)\end{array}$ & $\begin{array}{c}-0.024 \\
(0.031)\end{array}$ & $\begin{array}{c}0.002 \\
(0.020)\end{array}$ & $\begin{array}{l}-0.017 \\
(0.018)\end{array}$ & $\begin{array}{l}-0.004 \\
(0.033)\end{array}$ & $\begin{array}{l}-0.018 \\
(0.031)\end{array}$ & $\begin{array}{c}0.003 \\
(0.020)\end{array}$ \\
\hline Distance & $\begin{array}{l}-0.001 \\
(0.001)\end{array}$ & $\begin{array}{l}0.003^{* * *} \\
(0.002)\end{array}$ & $\begin{array}{l}0.003^{* *} \\
(0.002)\end{array}$ & $\begin{array}{l}-0.000 \\
(0.001)\end{array}$ & $\begin{array}{l}-0.001 \\
(0.001)\end{array}$ & $\begin{array}{l}0.003^{* * *} \\
(0.002)\end{array}$ & $\begin{array}{l}0.003^{* *} \\
(0.002)\end{array}$ & $\begin{array}{l}-0.000 \\
(0.001)\end{array}$ \\
\hline Committee & $\begin{array}{l}-0.006 \\
(0.012)\end{array}$ & $\begin{array}{l}-0.003 \\
(0.020)\end{array}$ & $\begin{array}{c}0.014 \\
(0.021)\end{array}$ & $\begin{array}{c}0.009 \\
(0.011)\end{array}$ & $\begin{array}{l}-0.008 \\
(0.012)\end{array}$ & $\begin{array}{l}-0.004 \\
(0.020)\end{array}$ & $\begin{array}{c}0.015 \\
(0.022)\end{array}$ & $\begin{array}{c}0.010 \\
(0.011)\end{array}$ \\
\hline $\mathrm{NGO}$ & $\begin{array}{c}0.002 \\
(0.016)\end{array}$ & $\begin{array}{c}0.033 \\
(0.026)\end{array}$ & $\begin{array}{c}0.027 \\
(0.028)\end{array}$ & $\begin{array}{c}0.002 \\
(0.014)\end{array}$ & $\begin{array}{c}0.003 \\
(0.016)\end{array}$ & $\begin{array}{c}0.033 \\
(0.026)\end{array}$ & $\begin{array}{c}0.026 \\
(0.028)\end{array}$ & $\begin{array}{c}0.003 \\
(0.014)\end{array}$ \\
\hline Conflict & $\begin{array}{l}-0.000 \\
(0.001)\end{array}$ & $\begin{array}{c}0.001 \\
(0.001)\end{array}$ & $\begin{array}{c}0.001 \\
(0.001)\end{array}$ & $\begin{array}{c}0.000 \\
(0.001)\end{array}$ & $\begin{array}{l}-0.000 \\
(0.001)\end{array}$ & $\begin{array}{c}0.001 \\
(0.001)\end{array}$ & $\begin{array}{c}0.001 \\
(0.001)\end{array}$ & $\begin{array}{l}-0.000 \\
(0.001)\end{array}$ \\
\hline Ethnic & $\begin{array}{c}0.002 \\
(0.027)\end{array}$ & $\begin{array}{l}0.090^{* *} \\
(0.046)\end{array}$ & $\begin{array}{c}0.035 \\
(0.049)\end{array}$ & $\begin{array}{c}0.010 \\
(0.024)\end{array}$ & $\begin{array}{l}-0.002 \\
(0.027)\end{array}$ & $\begin{array}{c}0.086^{*} \\
(0.046)\end{array}$ & $\begin{array}{c}0.032 \\
(0.050)\end{array}$ & $\begin{array}{c}0.006 \\
(0.024)\end{array}$ \\
\hline Isolation & $\begin{array}{c}-0.001^{* *} \\
(0.001)\end{array}$ & $\begin{array}{c}-0.002^{* * *} \\
(0.001)\end{array}$ & $\begin{array}{c}-0.002^{* *} \\
(0.001)\end{array}$ & $\begin{array}{c}-0.001^{\text {** }} \\
(0.000)\end{array}$ & $\begin{array}{c}-0.002^{* *} \\
(0.001)\end{array}$ & $\begin{array}{c}-0.002^{* * *} \\
(0.001)\end{array}$ & $\begin{array}{c}-0.002^{* *} \\
(0.001)\end{array}$ & $\begin{array}{c}-0.001^{* *} \\
(0.000)\end{array}$ \\
\hline FEs & $\mathrm{Y}$ & $\mathrm{Y}$ & $\mathrm{Y}$ & $\mathrm{Y}$ & $\mathrm{Y}$ & $\mathrm{Y}$ & $\bar{Y}$ & $\bar{Y}$ \\
\hline Sample & All & U7 & U7 & U7 & All & U7 & U7 & U7 \\
\hline Kingdoms & 55 & 55 & 55 & 55 & 55 & 55 & 55 & 55 \\
\hline $\mathrm{N}$ & 16,245 & 5,231 & 5,233 & 5,166 & 15,933 & 5,120 & 5,122 & 5,055 \\
\hline
\end{tabular}

Notes: Table reports marginal effects from probit regressions with kingdom fixed effects, evaluated at the mean of the independent variables. Standard errors (clustered at the village level) in parentheses. * $\mathrm{p}<0.10, * * \mathrm{p}<0.05, * * * \mathrm{p}<0.01$. 
Finally, Table A9 provides results from regressing health outcomes on whether the chief is educated (in years of education), and whether they are literate.

Table A9. Democracy and Health Outcomes: Chief Educated and Chief Literate

\begin{tabular}{|c|c|c|c|c|c|c|c|c|}
\hline & $\begin{array}{c}(1) \\
\text { Severely ill }\end{array}$ & $\begin{array}{c}(2) \\
\text { Fever }\end{array}$ & $\begin{array}{c}(3) \\
\text { Cough }\end{array}$ & $\begin{array}{c}(4) \\
\text { Diarrhoea }\end{array}$ & $\begin{array}{c}(5) \\
\text { Severely ill }\end{array}$ & $\begin{array}{c}(6) \\
\text { Fever }\end{array}$ & $\begin{array}{c}(7) \\
\text { Cough }\end{array}$ & $\begin{array}{c}(8) \\
\text { Diarrhoea }\end{array}$ \\
\hline Chief Educated & $\begin{array}{c}0.000 \\
(0.002)\end{array}$ & $\begin{array}{c}0.002 \\
(0.003)\end{array}$ & $\begin{array}{l}-0.002 \\
(0.003)\end{array}$ & $\begin{array}{c}0.001 \\
(0.002)\end{array}$ & & & & \\
\hline Chief Literate & & & & & $\begin{array}{l}-0.032^{*} \\
(0.018)\end{array}$ & $\begin{array}{c}-0.002 \\
(0.027)\end{array}$ & $\begin{array}{l}-0.052^{*} \\
(0.027)\end{array}$ & $\begin{array}{l}-0.006 \\
(0.014)\end{array}$ \\
\hline Male & $\begin{array}{c}-0.038^{* * * *} \\
(0.006)\end{array}$ & $\begin{array}{l}-0.018 \\
(0.014)\end{array}$ & $\begin{array}{c}-0.022 \\
(0.015)\end{array}$ & $\begin{array}{l}-0.012 \\
(0.009)\end{array}$ & $\begin{array}{c}-0.044^{* * * *} \\
(0.005)\end{array}$ & $\begin{array}{l}-0.023^{*} \\
(0.012)\end{array}$ & $\begin{array}{c}-0.016 \\
(0.012)\end{array}$ & $\begin{array}{l}-0.014 \\
(0.008)\end{array}$ \\
\hline Age & $\begin{array}{l}-0.009 \\
(0.006)\end{array}$ & $\begin{array}{c}0.140 \\
(0.121)\end{array}$ & $\begin{array}{l}-0.147 \\
(0.121)\end{array}$ & $\begin{array}{c}-0.359^{* * *} \\
(0.076)\end{array}$ & $\begin{array}{c}0.005 \\
(0.006)\end{array}$ & $\begin{array}{c}0.085 \\
(0.105)\end{array}$ & $\begin{array}{c}-0.054 \\
(0.099)\end{array}$ & $\begin{array}{c}-0.279^{* * *} \\
(0.065)\end{array}$ \\
\hline $\mathrm{Age}^{2}$ & $\begin{array}{c}0.005^{* * *} \\
(0.001)\end{array}$ & $\begin{array}{c}-0.354^{* * * *} \\
(0.118)\end{array}$ & $\begin{array}{l}-0.087 \\
(0.115)\end{array}$ & $\begin{array}{l}0.167^{* * *} \\
(0.076)\end{array}$ & $\begin{array}{c}0.004^{* * *} \\
(0.001)\end{array}$ & $\begin{array}{c}-0.291^{* * *} \\
(0.100)\end{array}$ & $\begin{array}{l}-0.152 \\
(0.094)\end{array}$ & $\begin{array}{l}0.114^{*} \\
(0.065)\end{array}$ \\
\hline Education & $\begin{array}{c}-0.003^{* *} \\
(0.001)\end{array}$ & $\begin{array}{c}-0.008^{* * * *} \\
(0.002)\end{array}$ & $\begin{array}{l}-0.003 \\
(0.002)\end{array}$ & $\begin{array}{c}-0.004^{* * * *} \\
(0.001)\end{array}$ & $\begin{array}{c}-0.003^{* *} \\
(0.001)\end{array}$ & $\begin{array}{c}-0.007^{* * * *} \\
(0.002)\end{array}$ & $\begin{array}{c}-0.003 \\
(0.002)\end{array}$ & $\begin{array}{c}-0.004^{* * *} \\
(0.001)\end{array}$ \\
\hline Wealth & $\begin{array}{l}-0.002 \\
(0.017)\end{array}$ & $\begin{array}{l}-0.030 \\
(0.034)\end{array}$ & $\begin{array}{l}-0.045 \\
(0.034)\end{array}$ & $\begin{array}{c}0.006 \\
(0.021)\end{array}$ & $\begin{array}{l}-0.021 \\
(0.017)\end{array}$ & $\begin{array}{l}-0.020 \\
(0.031)\end{array}$ & $\begin{array}{l}-0.020 \\
(0.029)\end{array}$ & $\begin{array}{c}0.005 \\
(0.019)\end{array}$ \\
\hline Distance & $\begin{array}{c}-0.004^{* * *} \\
(0.001)\end{array}$ & $\begin{array}{c}0.001 \\
(0.001)\end{array}$ & $\begin{array}{c}0.001 \\
(0.002)\end{array}$ & $\begin{array}{l}-0.000 \\
(0.001)\end{array}$ & $\begin{array}{l}-0.001 \\
(0.001)\end{array}$ & $\begin{array}{l}0.003^{* *} \\
(0.002)\end{array}$ & $\begin{array}{l}0.003^{* *} \\
(0.002)\end{array}$ & $\begin{array}{l}-0.000 \\
(0.001)\end{array}$ \\
\hline Committee & $\begin{array}{c}0.006 \\
(0.012)\end{array}$ & $\begin{array}{l}-0.012 \\
(0.022)\end{array}$ & $\begin{array}{c}-0.002 \\
(0.023)\end{array}$ & $\begin{array}{c}0.000 \\
(0.012)\end{array}$ & $\begin{array}{l}-0.003 \\
(0.012)\end{array}$ & $\begin{array}{c}-0.014 \\
(0.019)\end{array}$ & $\begin{array}{c}0.010 \\
(0.021)\end{array}$ & $\begin{array}{c}0.001 \\
(0.010)\end{array}$ \\
\hline NGO & $\begin{array}{l}-0.022 \\
(0.014)\end{array}$ & $\begin{array}{l}0.050^{*} \\
(0.029)\end{array}$ & $\begin{array}{c}0.006 \\
(0.031)\end{array}$ & $\begin{array}{c}0.000 \\
(0.016)\end{array}$ & $\begin{array}{c}0.002 \\
(0.015)\end{array}$ & $\begin{array}{c}0.023 \\
(0.024)\end{array}$ & $\begin{array}{c}0.014 \\
(0.026)\end{array}$ & $\begin{array}{l}-0.002 \\
(0.013)\end{array}$ \\
\hline Conflict & $\begin{array}{c}0.000 \\
(0.001)\end{array}$ & $\begin{array}{l}0.002^{* * *} \\
(0.001)\end{array}$ & $\begin{array}{c}0.002^{* * *} \\
(0.001)\end{array}$ & $\begin{array}{c}0.000 \\
(0.001)\end{array}$ & $\begin{array}{c}0.000 \\
(0.001)\end{array}$ & $\begin{array}{c}0.002^{* * *} \\
(0.001)\end{array}$ & $\begin{array}{c}0.002^{* * *} \\
(0.001)\end{array}$ & $\begin{array}{c}0.000 \\
(0.001)\end{array}$ \\
\hline Ethnic & $\begin{array}{c}0.008 \\
(0.024)\end{array}$ & $\begin{array}{l}0.085^{*} \\
(0.047)\end{array}$ & $\begin{array}{c}0.014 \\
(0.051)\end{array}$ & $\begin{array}{c}0.018 \\
(0.027)\end{array}$ & $\begin{array}{c}0.002 \\
(0.025)\end{array}$ & $\begin{array}{l}0.096^{* *} \\
(0.043)\end{array}$ & $\begin{array}{c}0.039 \\
(0.046)\end{array}$ & $\begin{array}{c}0.020 \\
(0.023)\end{array}$ \\
\hline Isolation & $\begin{array}{c}0.000 \\
(0.000)\end{array}$ & $\begin{array}{l}-0.001 \\
(0.001)\end{array}$ & $\begin{array}{l}-0.001 \\
(0.001)\end{array}$ & $\begin{array}{l}-0.000 \\
(0.001)\end{array}$ & $\begin{array}{c}-0.001^{* *} \\
(0.001)\end{array}$ & $\begin{array}{c}-0.002^{* *} \\
(0.001)\end{array}$ & $\begin{array}{c}-0.002^{* *} \\
(0.001)\end{array}$ & $\begin{array}{c}-0.001^{* * *} \\
(0.000)\end{array}$ \\
\hline FEs & $\mathrm{Y}$ & $\mathrm{Y}$ & $\mathrm{Y}$ & $\mathrm{Y}$ & $\mathrm{Y}$ & $\mathrm{Y}$ & $\mathrm{Y}$ & $\mathrm{Y}$ \\
\hline Sample & All & U7 & U7 & U7 & All & U7 & U7 & U7 \\
\hline Kingdoms & 55 & 55 & 55 & 55 & 55 & 55 & 55 & 55 \\
\hline $\mathrm{N}$ & 11,614 & 3,857 & 3,856 & 3,801 & 17,808 & 5,778 & 5,780 & 5,703 \\
\hline
\end{tabular}

Notes: Table reports marginal effects from probit regressions with kingdom fixed effects, evaluated at the mean of the independent variables. Standard errors (clustered at the village level) in parentheses. * $\mathrm{p}<0.10, * * \mathrm{p}<0.05, * * * \mathrm{p}<0.01$. 


\section{Online Appendix: Robustness Test. Parsimonious Model}

Table A10 presents the relationship between democracy and exposure to democracy and health outcomes, where we control solely for gender of the individual and the education level of the head of the household.

Table A10. Democracy and Health Outcomes

\begin{tabular}{lcccc|cccc}
\hline & $\begin{array}{c}(1) \\
\text { Severely ill }\end{array}$ & $\begin{array}{c}(2) \\
\text { Fever }\end{array}$ & $\begin{array}{c}(3) \\
\text { Cough }\end{array}$ & $\begin{array}{c}(4) \\
\text { Diarrhoea }\end{array}$ & $\begin{array}{c}(5) \\
\text { Severely ill }\end{array}$ & $\begin{array}{c}(6) \\
\text { Fever }\end{array}$ & $\begin{array}{c}(7) \\
\text { Cough }\end{array}$ & $\begin{array}{c}(8) \\
\text { Diarrhoea }\end{array}$ \\
\hline Democracy & -0.005 & -0.004 & 0.010 & 0.005 & & & & \\
& $(0.010)$ & $(0.019)$ & $(0.019)$ & $(0.010)$ & & & & \\
Exposure & & & & & -0.000 & 0.000 & 0.001 & 0.000 \\
& & & & & $(0.001)$ & $(0.001)$ & $(0.001)$ & $(0.001)$ \\
\hline Male & $-0.043^{* * *}$ & $-0.020^{*}$ & $-0.020^{*}$ & $-0.018^{* *}$ & $-0.043^{* * *}$ & $-0.021^{*}$ & $-0.022^{* *}$ & $-0.018^{* *}$ \\
& $(0.005)$ & $(0.01)^{* *}$ & $(0.011)$ & $(0.007)$ & $(0.005)$ & $(0.011)^{* *}$ & $(0.011)$ & $(0.007)$ \\
Education & $-0.004^{* * *}$ & $-0.007^{* * *}$ & $-0.003^{*}$ & $-0.003^{* * *}$ & $-0.004^{* * *}$ & $-0.007^{* * *}$ & -0.003 & $-0.003^{* * *}$ \\
& $(0.001)$ & $(0.002)$ & $(0.002)$ & $(0.001)$ & $(0.001)$ & $(0.002)$ & $(0.002)$ & $(0.001)$ \\
\hline FEs & $\mathrm{Y}$ & $\mathrm{Y}$ & $\mathrm{Y}$ & $\mathrm{Y}$ & $\mathrm{Y}$ & $\mathrm{Y}$ & $\mathrm{Y}$ & $\mathrm{Y}$ \\
Sample & $\mathrm{A} 11$ & $\mathrm{U} 7$ & $\mathrm{U} 7$ & $\mathrm{U} 7$ & $\mathrm{~A} 11$ & $\mathrm{U} 7$ & $\mathrm{U} 7$ & $\mathrm{U} 7$ \\
Kingdoms & 55 & 55 & 55 & 55 & 55 & 55 & 55 & 55 \\
$\mathrm{~N}$ & 22,824 & 7,113 & 7,118 & 7,047 & 22,981 & 7,163 & 7,167 & 7,098 \\
\hline
\end{tabular}

Notes: Table reports marginal effects from probit regressions with kingdom fixed effects, evaluated at the mean of the independent variables. Standard errors (clustered at the village level) in parentheses. * $\mathrm{p}<0.10, * * \mathrm{p}<0.05, * * * \mathrm{p}<0.01$ 


\section{Online Appendix: Results by Age Group}

Table A11 presents the relationship between democracy and health (severely ill) by age groups. We explore three groups: those under seven years old, those under eighteen, and adults (those above eighteen).

Table A11. Democracy and Health Outcomes by age group

\begin{tabular}{|c|c|c|c|c|c|c|}
\hline & $\begin{array}{c}(1) \\
\text { Severely ill }\end{array}$ & $\begin{array}{c}(2) \\
\text { Severely ill }\end{array}$ & $\begin{array}{c}(3) \\
\text { Severely ill }\end{array}$ & $\begin{array}{c}(5) \\
\text { Severely ill }\end{array}$ & $\begin{array}{c}(6) \\
\text { Severely ill }\end{array}$ & $\begin{array}{c}(7) \\
\text { Severely ill }\end{array}$ \\
\hline Democracy & $\begin{array}{l}-0.012 \\
(0.015)\end{array}$ & $\begin{array}{c}-0.013 \\
(0.011)\end{array}$ & $\begin{array}{c}-0.011 \\
(0.014)\end{array}$ & & & \\
\hline Exposure & & & & $\begin{array}{c}0.000 \\
(0.001) \\
\end{array}$ & $\begin{array}{c}-0.001 \\
(0.001)\end{array}$ & $\begin{array}{c}-0.001 \\
(0.001)\end{array}$ \\
\hline Male & $\begin{array}{l}-0.007 \\
(0.011)\end{array}$ & $\begin{array}{l}-0.004 \\
(0.007)\end{array}$ & $\begin{array}{c}-0.085^{* * *} \\
(0.008)\end{array}$ & $\begin{array}{l}-0.007 \\
(0.011)\end{array}$ & $\begin{array}{l}-0.004 \\
(0.007)\end{array}$ & $\begin{array}{c}-0.084^{\text {**** }} \\
(0.008)\end{array}$ \\
\hline Age & $\begin{array}{c}0.222 \\
(0.140)\end{array}$ & $\begin{array}{c}-0.129^{* * *} \\
(0.028)\end{array}$ & $\begin{array}{c}0.068^{* * *} \\
(0.014)\end{array}$ & $\begin{array}{c}0.232^{*} \\
(0.138)\end{array}$ & $\begin{array}{c}-0.136^{* * * *} \\
(0.028)\end{array}$ & $\begin{array}{c}0.070^{* * * *} \\
(0.014)\end{array}$ \\
\hline $\mathrm{Age}^{2}$ & $\begin{array}{c}-0.399^{* *} \\
(0.170)\end{array}$ & $\begin{array}{c}0.046^{* * *} \\
(0.015)\end{array}$ & $\begin{array}{l}-0.003^{*} \\
(0.002)\end{array}$ & $\begin{array}{c}-0.418^{* *} \\
(0.169)\end{array}$ & $\begin{array}{c}0.049^{* * *} \\
(0.015)\end{array}$ & $\begin{array}{c}-0.003^{* *} \\
(0.002)\end{array}$ \\
\hline Education & $\begin{array}{l}-0.004^{*} \\
(0.002)\end{array}$ & $\begin{array}{c}-0.003^{* *} \\
(0.001)\end{array}$ & $\begin{array}{l}-0.003 \\
(0.002)\end{array}$ & $\begin{array}{c}-0.004^{* *} \\
(0.002)\end{array}$ & $\begin{array}{c}-0.003^{* *} \\
(0.001)\end{array}$ & $\begin{array}{l}-0.003 \\
(0.002)\end{array}$ \\
\hline Wealth & $\begin{array}{c}0.012 \\
(0.028)\end{array}$ & $\begin{array}{c}-0.003 \\
(0.018)\end{array}$ & $\begin{array}{l}-0.033 \\
(0.021)\end{array}$ & $\begin{array}{c}0.008 \\
(0.027)\end{array}$ & $\begin{array}{l}-0.004 \\
(0.018)\end{array}$ & $\begin{array}{l}-0.032 \\
(0.021)\end{array}$ \\
\hline Distance & $\begin{array}{l}-0.001 \\
(0.002)\end{array}$ & $\begin{array}{l}-0.002 \\
(0.001)\end{array}$ & $\begin{array}{l}-0.001 \\
(0.001)\end{array}$ & $\begin{array}{l}-0.001 \\
(0.002)\end{array}$ & $\begin{array}{l}-0.002 \\
(0.001)\end{array}$ & $\begin{array}{l}-0.001 \\
(0.001)\end{array}$ \\
\hline Committee & $\begin{array}{c}0.014 \\
(0.016)\end{array}$ & $\begin{array}{c}0.005 \\
(0.012)\end{array}$ & $\begin{array}{l}-0.011 \\
(0.015)\end{array}$ & $\begin{array}{c}0.015 \\
(0.016)\end{array}$ & $\begin{array}{c}0.005 \\
(0.012)\end{array}$ & $\begin{array}{l}-0.010 \\
(0.014)\end{array}$ \\
\hline NGO & $\begin{array}{c}0.058^{* * *} \\
(0.022)\end{array}$ & $\begin{array}{c}0.005 \\
(0.016)\end{array}$ & $\begin{array}{l}-0.011 \\
(0.018)\end{array}$ & $\begin{array}{l}0.055^{* *} \\
(0.022)\end{array}$ & $\begin{array}{c}0.002 \\
(0.016)\end{array}$ & $\begin{array}{l}-0.014 \\
(0.017)\end{array}$ \\
\hline Conflict & $\begin{array}{c}0.000 \\
(0.001)\end{array}$ & $\begin{array}{c}0.000 \\
(0.000)\end{array}$ & $\begin{array}{l}-0.001 \\
(0.001)\end{array}$ & $\begin{array}{c}0.001 \\
(0.001)\end{array}$ & $\begin{array}{c}0.000 \\
(0.000)\end{array}$ & $\begin{array}{c}-0.000 \\
(0.001)\end{array}$ \\
\hline Ethnic & $\begin{array}{l}-0.005 \\
(0.034)\end{array}$ & $\begin{array}{l}-0.035 \\
(0.027)\end{array}$ & $\begin{array}{c}0.019 \\
(0.032)\end{array}$ & $\begin{array}{l}-0.003 \\
(0.034)\end{array}$ & $\begin{array}{l}-0.033 \\
(0.027)\end{array}$ & $\begin{array}{c}0.012 \\
(0.031)\end{array}$ \\
\hline Isolation & $\begin{array}{l}-0.001 \\
(0.001)\end{array}$ & $\begin{array}{c}-0.002^{* * *} \\
(0.001)\end{array}$ & $\begin{array}{l}-0.001 \\
(0.001)\end{array}$ & $\begin{array}{l}-0.001 \\
(0.001)\end{array}$ & $\begin{array}{c}-0.002^{* *} \\
(0.001)\end{array}$ & $\begin{array}{l}-0.001 \\
(0.001)\end{array}$ \\
\hline FEs & $\mathrm{Y}$ & $\mathrm{Y}$ & $\mathrm{Y}$ & $\mathrm{Y}$ & $\mathrm{Y}$ & $\mathrm{Y}$ \\
\hline Sample & U7 & U18 & $>18$ & U7 & U18 & $>18$ \\
\hline Kingdoms & 55 & 55 & 55 & 55 & 55 & 55 \\
\hline $\mathrm{N}$ & 3,948 & 9,255 & 9,092 & 3,982 & 9,333 & 9,177 \\
\hline
\end{tabular}

Notes: Marginal effects from probit regressions with kingdom fixed effects. Standard errors (clustered at the village level) in parentheses. ${ }^{*} \mathrm{p}<0.10,{ }^{*} \mathrm{p}<0.05,{ }^{* * *} \mathrm{p}<0.01$. 


\section{Online Appendix: Results Relating to Table 2 Including Household Size}

In this section we add household size as a control variable to the regressions. The average household size is 7.73 individuals (standard deviation is 3.39 ) and the maximum household size is 27 . Table A12 presents the results. The results remain the same. We find that individuals in larger households are less sick and are less likely to have fever or cough. In the Congolese context, this could be an indication of wealth.

Table A12. Democracy and Health Outcomes Including Household Size as a Control

\begin{tabular}{|c|c|c|c|c|c|c|c|c|}
\hline & $\begin{array}{c}(1) \\
\text { Severely ill }\end{array}$ & $\begin{array}{l}(2) \\
\text { Flu }\end{array}$ & $\begin{array}{c}(3) \\
\text { Cough } \\
\end{array}$ & $\begin{array}{c}(4) \\
\text { Diarrhoea }\end{array}$ & $\begin{array}{c}(5) \\
\text { Severely ill } \\
\end{array}$ & $\begin{array}{l}(6) \\
\text { Flu }\end{array}$ & $\begin{array}{c}(7) \\
\text { Cough }\end{array}$ & $\begin{array}{c}(8) \\
\text { Diarrhoea }\end{array}$ \\
\hline Democracy & $\begin{array}{l}-0.012 \\
(0.011)\end{array}$ & $\begin{array}{l}-0.011 \\
(0.020)\end{array}$ & $\begin{array}{c}0.001 \\
(0.022)\end{array}$ & $\begin{array}{c}0.002 \\
(0.011)\end{array}$ & & & & \\
\hline Exposure & & & & & $\begin{array}{l}-0.001 \\
(0.001)\end{array}$ & $\begin{array}{l}-0.000 \\
(0.001) \\
\end{array}$ & $\begin{array}{c}0.001 \\
(0.001)\end{array}$ & $\begin{array}{c}-0.000 \\
(0.001)\end{array}$ \\
\hline Male & $\begin{array}{c}-0.046^{* * * *} \\
(0.005)\end{array}$ & $\begin{array}{c}-0.024^{* *} \\
(0.012)\end{array}$ & $\begin{array}{l}-0.022^{*} \\
(0.012)\end{array}$ & $\begin{array}{c}-0.016^{* *} \\
(0.008)\end{array}$ & $\begin{array}{c}-0.045^{\text {**** }} \\
(0.005)\end{array}$ & $\begin{array}{c}-0.025^{* *} \\
(0.012)\end{array}$ & $\begin{array}{c}-0.024^{* * *} \\
(0.012)\end{array}$ & $\begin{array}{c}-0.016^{* * *} \\
(0.008)\end{array}$ \\
\hline Age & $\begin{array}{c}0.008 \\
(0.006)\end{array}$ & $\begin{array}{c}0.074 \\
(0.107)\end{array}$ & $\begin{array}{l}-0.085 \\
(0.099)\end{array}$ & $\begin{array}{c}-0.282^{* * *} \\
(0.066)\end{array}$ & $\begin{array}{c}0.006 \\
(0.006)\end{array}$ & $\begin{array}{c}0.089 \\
(0.106)\end{array}$ & $\begin{array}{c}-0.038 \\
(0.100)\end{array}$ & $\begin{array}{c}-0.287^{* * *} \\
(0.065)\end{array}$ \\
\hline $\mathrm{Age}^{2}$ & $\begin{array}{l}0.003^{* * *} \\
(0.001)\end{array}$ & $\begin{array}{c}-0.274^{* * *} \\
(0.101)\end{array}$ & $\begin{array}{l}-0.123 \\
(0.094)\end{array}$ & $\begin{array}{l}0.119^{*} \\
(0.066)\end{array}$ & $\begin{array}{l}0.003^{\text {**** }} \\
(0.001)\end{array}$ & $\begin{array}{c}-0.296^{* * *} \\
(0.101)\end{array}$ & $\begin{array}{l}-0.173^{*} \\
(0.095)\end{array}$ & $\begin{array}{l}0.121^{*} \\
(0.065)\end{array}$ \\
\hline Education & $\begin{array}{l}-0.002^{*} \\
(0.001)\end{array}$ & $\begin{array}{c}-0.007^{* * *} \\
(0.002)\end{array}$ & $\begin{array}{c}-0.003 \\
(0.002)\end{array}$ & $\begin{array}{c}-0.004^{* * *} \\
(0.001)\end{array}$ & $\begin{array}{l}-0.002^{*} \\
(0.001)\end{array}$ & $\begin{array}{c}-0.007^{* * *} \\
(0.002)\end{array}$ & $\begin{array}{c}-0.003 \\
(0.002)\end{array}$ & $\begin{array}{c}-0.004^{* * *} \\
(0.001)\end{array}$ \\
\hline Wealth & $\begin{array}{l}-0.016 \\
(0.017)\end{array}$ & $\begin{array}{l}-0.008 \\
(0.031)\end{array}$ & $\begin{array}{l}-0.009 \\
(0.030)\end{array}$ & $\begin{array}{c}0.009 \\
(0.019)\end{array}$ & $\begin{array}{l}-0.016 \\
(0.017)\end{array}$ & $\begin{array}{l}-0.011 \\
(0.031)\end{array}$ & $\begin{array}{c}-0.011 \\
(0.030)\end{array}$ & $\begin{array}{c}0.007 \\
(0.019)\end{array}$ \\
\hline Distance & $\begin{array}{c}-0.002 \\
(0.001)\end{array}$ & $\begin{array}{l}0.003^{* *} \\
(0.001)\end{array}$ & $\begin{array}{l}0.003^{* *} \\
(0.002)\end{array}$ & $\begin{array}{l}-0.000 \\
(0.001)\end{array}$ & $\begin{array}{l}-0.002 \\
(0.001)\end{array}$ & $\begin{array}{l}0.003^{*} \\
(0.001)\end{array}$ & $\begin{array}{l}0.003^{*} \\
(0.002)\end{array}$ & $\begin{array}{l}-0.000 \\
(0.001)\end{array}$ \\
\hline Committee & $\begin{array}{l}-0.004 \\
(0.012)\end{array}$ & $\begin{array}{l}-0.010 \\
(0.019)\end{array}$ & $\begin{array}{c}0.013 \\
(0.021)\end{array}$ & $\begin{array}{c}0.004 \\
(0.010)\end{array}$ & $\begin{array}{l}-0.003 \\
(0.012)\end{array}$ & $\begin{array}{l}-0.011 \\
(0.019)\end{array}$ & $\begin{array}{c}0.011 \\
(0.020)\end{array}$ & $\begin{array}{c}0.003 \\
(0.010)\end{array}$ \\
\hline $\mathrm{NGO}$ & $\begin{array}{l}-0.001 \\
(0.015)\end{array}$ & $\begin{array}{c}0.024 \\
(0.025)\end{array}$ & $\begin{array}{c}0.013 \\
(0.026)\end{array}$ & $\begin{array}{l}-0.002 \\
(0.013)\end{array}$ & $\begin{array}{l}-0.003 \\
(0.015)\end{array}$ & $\begin{array}{c}0.021 \\
(0.025)\end{array}$ & $\begin{array}{c}0.011 \\
(0.026)\end{array}$ & $\begin{array}{l}-0.001 \\
(0.013)\end{array}$ \\
\hline Conflict & $\begin{array}{l}-0.000 \\
(0.001)\end{array}$ & $\begin{array}{c}0.001 \\
(0.001)\end{array}$ & $\begin{array}{c}0.001^{*} \\
(0.001)\end{array}$ & $\begin{array}{c}0.000 \\
(0.001)\end{array}$ & $\begin{array}{c}0.000 \\
(0.001)\end{array}$ & $\begin{array}{c}0.001 \\
(0.001)\end{array}$ & $\begin{array}{c}0.001^{*} \\
(0.001)\end{array}$ & $\begin{array}{c}0.000 \\
(0.001)\end{array}$ \\
\hline Ethnic & $\begin{array}{l}-0.001 \\
(0.026)\end{array}$ & $\begin{array}{l}0.097^{* *} \\
(0.043)\end{array}$ & $\begin{array}{c}0.032 \\
(0.046)\end{array}$ & $\begin{array}{c}0.013 \\
(0.023)\end{array}$ & $\begin{array}{l}-0.003 \\
(0.025)\end{array}$ & $\begin{array}{l}0.100^{* *} \\
(0.043)\end{array}$ & $\begin{array}{c}0.035 \\
(0.046)\end{array}$ & $\begin{array}{c}0.016 \\
(0.023)\end{array}$ \\
\hline Isolation & $\begin{array}{c}-0.0011^{* *} \\
(0.001)\end{array}$ & $\begin{array}{c}-0.002^{* * * *} \\
(0.001)\end{array}$ & $\begin{array}{c}-0.002^{* *} \\
(0.001)\end{array}$ & $\begin{array}{c}-0.001^{* *} \\
(0.000)\end{array}$ & $\begin{array}{c}-0.001^{\text {** }} \\
(0.001)\end{array}$ & $\begin{array}{c}-0.002^{* * *} \\
(0.001)\end{array}$ & $\begin{array}{c}-0.002^{* *} \\
(0.001)\end{array}$ & $\begin{array}{c}-0.001^{* *} \\
(0.000)\end{array}$ \\
\hline HH size & $\begin{array}{c}-0.004^{* *} \\
(0.002)\end{array}$ & $\begin{array}{l}-0.005 \\
(0.003)\end{array}$ & $\begin{array}{l}-0.006^{*} \\
(0.003)\end{array}$ & $\begin{array}{c}-0.001 \\
(0.002)\end{array}$ & $\begin{array}{c}-0.004^{* *} \\
(0.002)\end{array}$ & $\begin{array}{c}-0.004 \\
(0.003)\end{array}$ & $\begin{array}{l}-0.006^{*} \\
(0.003)\end{array}$ & $\begin{array}{l}-0.001 \\
(0.002)\end{array}$ \\
\hline FEs & $\mathrm{Y}$ & $\mathrm{Y}$ & $\mathrm{Y}$ & $\mathrm{Y}$ & $\mathrm{Y}$ & $\mathrm{Y}$ & $\mathrm{Y}$ & $\mathrm{Y}$ \\
\hline Sample & All & U7 & U7 & U7 & All & U7 & U7 & U7 \\
\hline Kingdoms & 55 & 55 & 55 & 55 & 55 & 55 & 55 & 55 \\
\hline $\mathrm{N}$ & 17,602 & 5,698 & 5,700 & 5,623 & 17,759 & 5,749 & 5,751 & 5,676 \\
\hline
\end{tabular}

Notes: Marginal effects from probit regressions with kingdom fixed effects. Standard errors (clustered at the village level) in parentheses. ${ }^{*} \mathrm{p}<0.10,{ }^{* *} \mathrm{p}<0.05,{ }^{* * *} \mathrm{p}<0.01$. 